Late Quaternary Depositional History, Holocene Sea-Level Changes, and Vertical Crustal Movement, Southern San Francisco Bay, California

GE O L O G I C A L S U R V E Y P R F ESSIONAL PAPER 1014 
This page intentionally left blank 
LATE QUATERNARY DEPOSITIONAL HISTORY, HOLOCENE SEA-LEVEL CHANGES, AND VERTICAL CRUSTAL MOVEMENT, SOUTHERN SAN FRANCISCO BAY, CALIFORNIA 


\section{Late Quaternary Depositional History,}

Holocene Sea-Level Changes, and Vertical Crustal Movement, Southern San Francisco Bay, California

BY BRIAN F. ATWATER, CHARLES W. HEDEL, and EDWARD J. HELLEY

GEOLOGICALSURVEYPROFESSIONALPAPER 1014
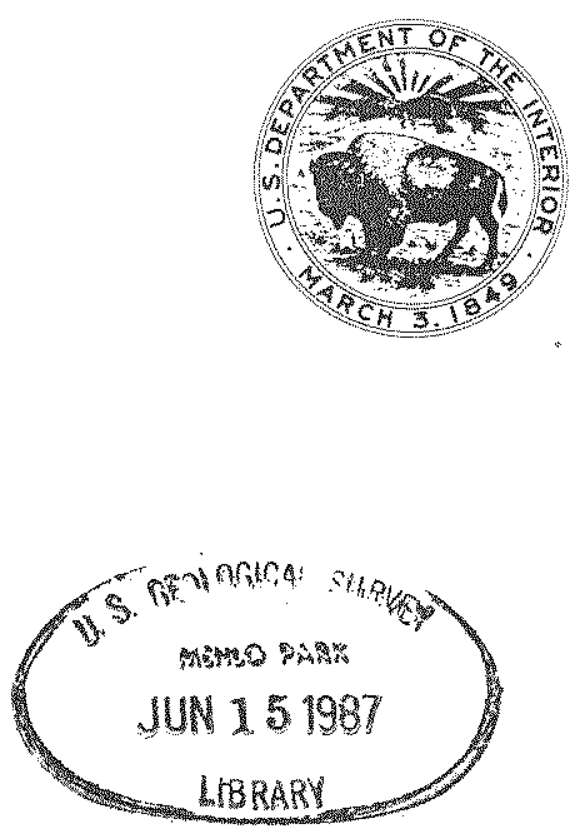

78575 


\section{UNITED STATES DEPARTMENT OF THE INTERIOR}

CECIL D. ANDRUS, Secretary

\section{GEOLOGICAL SURVEY}

V. E. Mckelvey, Direchr

Library of Congress Cataloging in Publication Data

Atwater, Brian F.

Late Quaternary depositional history, Holocene sea-fevel changes, and vertical crust movement, southern San Francisco Bay, California.

(Geologicals Survey Professional Paper 1014)

Bibliography: p. 14-15.

Supt. of Docs. No.: $119.16: 1014$

1. Geology, Stratigraphic-Quaternary. 2. Sea level-Pacific coast. 3. Earth movements-Californiam San Francisco Bay. I. Hedel, Charles W., joint author. II. Helley, Edward J., joint author. III. Title:Late quaternary depositional history,... IV. Series: United States Geological Survey profescional per 1014. QE696.A89

For sale by the Supcrintendent of Documents, U.S. Government Printing Office Washington, D.C. 20402

Stock Number 024-001-02966-9 


\section{CONTENTS}

\begin{tabular}{|c|c|c|}
\hline & & \\
\hline Abstract ... & Holocene sea levels-Continued & \\
\hline Introduction $\ldots \ldots \ldots$ & Numerical uncertainties in sea-level data - Continued & \\
\hline Acknowledgments .. & Postdepositional subsidence $\ldots \ldots \ldots \ldots \ldots \ldots$ & \\
\hline Methods $\ldots \ldots \ldots \ldots \ldots \ldots \ldots \ldots \ldots \ldots$ & The Holocene transgression $\ldots$. & \\
\hline Late Quaternary depositional history & Vertical movement of the Earth's crust .. & 12 \\
\hline Estuarine deposits $\ldots \ldots \ldots \ldots \ldots$ & Evidence and rates of subsidence $\ldots \ldots \ldots \ldots \ldots \ldots$ & 12 \\
\hline Terrestrial deposits $\ldots \ldots \ldots \ldots \ldots$ & Quatemary sediments at least $200 \mathrm{~m}$ below present & \\
\hline $\begin{array}{c}\text { Holocene sea levels } \ldots \ldots \ldots \ldots \ldots \ldots \ldots \ldots \ldots \ldots \ldots \ldots \ldots \\
\text { Relation of dated samples to former sea level }\end{array}$ & sea level $\ldots \ldots \ldots \ldots \ldots \ldots \ldots \ldots \ldots \ldots \ldots \ldots$ & 13 \\
\hline $\begin{array}{l}\text { Relation of dated samples to former sea levels } \ldots \ldots \\
\text { Salt-marsh deposits } \ldots \ldots \ldots \ldots, \ldots \ldots \ldots\end{array}$ & Wisconsin thalwegs higher than the deepest & \\
\hline $\begin{array}{l}\text { Salt-marsh deposits } \ldots \ldots \ldots \ldots \ldots \ldots \ldots \ldots \ldots \\
\text { Intertidal or uppermost subtidal deposits } \ldots \ldots \ldots\end{array}$ & Sangamon estuarine deposits $\ldots \ldots \ldots \ldots \ldots$ & \\
\hline $\begin{array}{l}\text { Intertidal or uppermost subtidal deposits } \ldots \ldots \ldots \text {, } \\
\text { Freshwater marsh deposits } \ldots \ldots \ldots \ldots \ldots \ldots\end{array}$ & $\begin{array}{l}\text { Relative sea-level rise greater than that expected } \\
\text { from eustatic sea-level }\end{array}$ & \\
\hline $\begin{array}{l}\text { Fresh water marsh deposits } \ldots \ldots \ldots \ldots \ldots \ldots \\
\text { Numerical uncertainties in sea-level data } \ldots \ldots \ldots\end{array}$ & $\begin{array}{l}\text { from eustatic sea-level changes alone } \ldots \ldots \ldots \ldots \\
\text { Age of the bedrock depression containing southern }\end{array}$ & \\
\hline Modern sample elevation $\ldots \ldots \ldots \ldots \ldots$ & 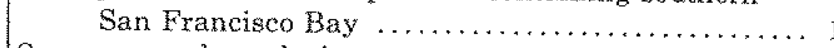 & \\
\hline Sample elevation at time of deposition & $\begin{array}{l}\text { Summary and conclusions } \ldots \ldots \ldots \ldots \ldots \ldots \ldots \ldots \ldots \ldots \ldots \\
\text { References cited } \ldots \ldots \ldots \ldots \ldots \ldots \ldots \ldots \ldots \ldots \ldots \ldots\end{array}$ & \\
\hline
\end{tabular}

\section{ILLUSTRATIONS}

PLATE 1. Cross sections showing late Quaternary sediments beneath southern San Francisco Bay, California page

Ficures 1. Map showing the modern San Francisco Bay estuary and adjacent continental-shelf area In pocket

2. Chart showing chronology for sediments under southern San Francisco Bay

3. Photographs of representative pelecypods from post-Wisconsin estuarine sediments under southern San Francisco Bay

4. Scanning electron micrographs of representative foraminifers, an ostracode, diatoms, and marsh-plant seeds from post-Wisconsin estuarine sediments under southern San Francisco Bay

5. Chart showing comparison of stratigraphic nomenclature for

6. Graph showing Holocene sea-level changes in the vicinity of southern San Francisco Bay San Francisco Bay .................. 9

7. Graph showing longitudinal profiles of buxied land surfaces under southern San Francisco Bay …......................................... 12

TABLE 1. Description and interpretation of sediments and bedrock under southern San Francisco Bay

2. Data on Holocene sea levels

3. Evidence and inferred rates of crustal down-warping in the vicinity of southern San Francisco Bay. 
This page intentionally left blank 


\title{
LATE QUATERNARY DEPOSITIONAL HISTORY, HOLOCENE SEA-LEVEL CHANGES, AND VERTICAL CRUSTAL MOVEMENT, SOUTHERN SAN FRANCISCO BAY, CALIFORNIA
}

\author{
By Brian F. Atwater, Charles W. Hedel, and Edward J. Helley
}

\begin{abstract}
Sediments collected for bridge foundation studies at southern San Francisco Bay, Calif, record estuaries that formed during Sangamon (100,000 years ago) and post-Wisconsin (less than 10,000 years ago) high stands of sea level, The estuarine deposits of Sangamon and post-Wisconsin ages are separated by alluvial and eolian deposits and by erosional unconformities and surfaces of nondeposition, features that indicate lowered base levels and ocean ward migrations of the shoreline accompanying low stands of the sea. Estuarine deposits of mid.Wisconsin age appear to be absent, suggesting that sea level was not near its present height $30,000-40,000$ years ago in central California.

Holocene sea-level changes are measured from the elevations and apparent ${ }^{14} \mathrm{C}$ ages of plant remains from 13 core samples. Uncertainties of \pm 2 to $\pm 4 \mathrm{~m}$ in the elevations of the dated sea levels represent the sum of exrors in determination of (1) sample elevation rela tive to present sea level, (2) sample elevation relative to sea level at the time of accumulation of the dated material, and (3) postdepositional subsidence of the sample due to compaction of underlying sediments.

Sea level in the vicinity of southern San Francisco Bay rose about $2 \mathrm{~cm} / \mathrm{yr}$ from 9,500 to 8,000 years ago. The rate of relative sea-level rise then declined about tenfold from 8,000 to 6,000 years ago, and it has averaged $0.1-0.2 \mathrm{~cm} / \mathrm{yr}$ from 6,000 years ago to the present. This submergence history indicates that the rising sea entered the Golden Gate 10,000-11,000 years ago and spread across land areas as rapidly as $30 \mathrm{~m} / \mathrm{yr}$ until 8,000 years ago. Subsequent shoreline changes were more gradual because of the decrease in rate of sea-level rise.

Some of the sediments under southem San Francisco Bay appear to be below the level at which they initially accumulated. The vertical crustal movement suggested by these sediments may be summarized as follows: (1) Some Quatemary(?) sediments have sustained at least $100 \mathrm{~m}$ of tectonic subsidence in less than 1.5 million years $(<0.07 \mathrm{~mm} / \mathrm{yr})$ relative to the likely elevation of the lowest Pleistocene land surface; (2) the deepest Sangamon estuarine deposits subsided tectonically about $20-40 \mathrm{~m}$ in about 0.1 million years $(0.2 \pm 0.1-0.4 \pm 0.1 \mathrm{~mm} / \mathrm{yr})$ relative to the assumed initial elevations of the thalwegs buried by these sediments; and (3) Holocene salt-marsh deposits have undergone about $5 \mathrm{~m}$ of tectonic and possibly isostatic subsidence in about 6,000 years $(0.8 \pm 0.7 \mathrm{~mm} / \mathrm{yr})$ relative to elevations which might be expected from eustatic sea-level changes alone.
\end{abstract}

\section{INTRODUCTION}

Geologists long ago recognized geomorphic evi- dence of late Quaternary sea-level changes in the San Francisco Bay area. Lawson (1894, p. 266) interpreted the numerous islands, peninsulas, and small embayments near San Francisco (fig. 1) as former hills, ridges, and stream valleys recently submerged by the sea. He suggested that San Francisco Bay did not exist prior to this submergence and that the ancestral drainage of the San JoaquinSacramento Rivers flowed through the Golden Gate to a coastline some distance west of the present one. Gilbert (1917, p. 16-24) cited partial submergence of aboriginal shell mounds and historic retreat of the bayward edges of salt marshes as evidence of an ongoing relative sea-level rise.

Both Lawson and Gilbert initially attributed these sea-level changes to tectonic subsidence of the land. Subsequently, Louderback (1941; 1951, p. 84, 86) suggested that San Francisco Bay was created by a worldwide sea-level rise of about $100 \mathrm{~m}$ caused by melting of late Pleistocene (Wisconsin) glaciers.

The purpose of this study is to elucidate the late Quaternary history of the site of southern San Francisco Bay by dating post-Wisconsin sea levels, documenting earlier sea-level fluctuations, and measuring vertical crustal movement. This history contributes to the understanding of the recent sedimentary and tectonic history of the densely populated area around southern San Francisco Bay. In addition, it accounts for the foundation characteristics of late Quaternary sediments beneath and peripheral to the bay. Finally, it provides a time perspective on the principal geographic features of the San Francisco Bay area.

\section{ACKNOWLEDGMENTS}

Most of the core samples on which this study is based were collected and logged by the California Division of Bay Toll Crossings. State engineers and geologists who participated in bridge foundation 


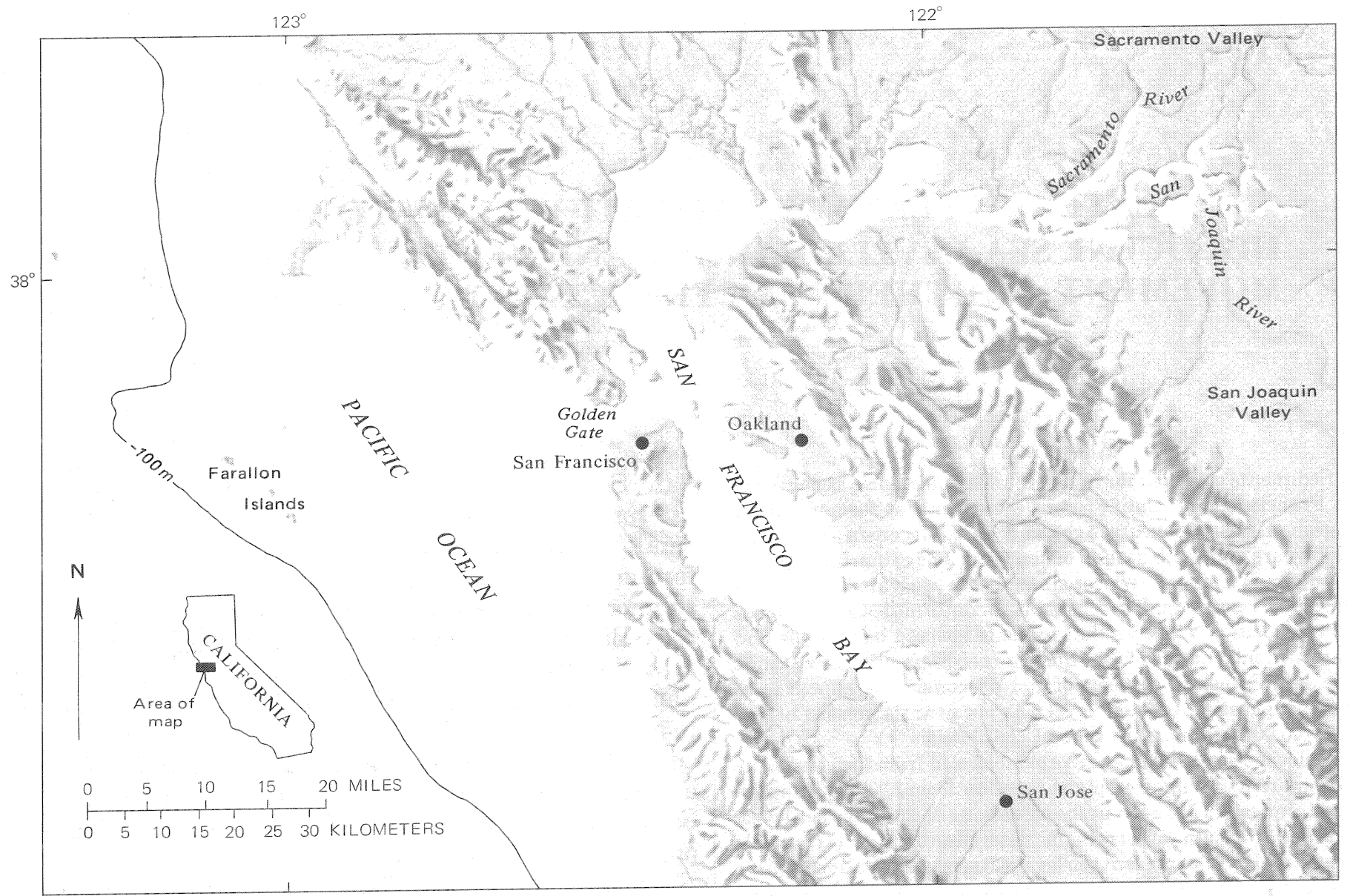

FrgURE 1.-Modern San Francisco Bay and adjacent continental-shelf area. As used in this report, southern San Francisco Bay refers to the part of the bay that lies south of the latitude of the Golden Gate. The $100-\mathrm{m}$ isobath approximatea the ahoreline position 15,000 years ago.

studies include: S. K. Atkinson, T. Baker, R. H. Barnwell, C. C. Bohannon, F. R. Carraro, T. Daukas, J. W. Driskill, G. G. Emerson, T. Fox, S. Hernon, H. S. Hunt, S. Kelsey, M. C. Knickelbein, B. McCreary, J. Marzotto, M. Matsumoto, D. Morgan, J. M. Oxendine, J. W. Rolston, R. S. Samuelson, W. R. Schott, W. M. Schwartz, P. D. Trask, C. Venskus, and J. E. Wright. Fossil identifications for this report were made by W. O. Addicott (mollusks and barnacles), J. A. Barron and C. W. Hedel (diatoms), R. E. Arnal and B. F. Atwater (foraminifers), and P. C. Valentine (ostracodes). Photographs of pelecypods were taken by Kenji Sakamoto, and scanning electron micrographs of microfossils were taken by Robert $\mathrm{L}$. Oscarson.

\section{METHODS}

The stratigraphy developed in this paper is based on samples collected for bridge foundation studies. Since 1946 the California Division of Bay Toll Crossings has contracted the drilling of approximately 600 boreholes into sediments under southern
San Francisco Bay. All of the boreholes penetrated firm terrestrial sediments beneath Holocene estuarine deposits, and some extended more than $100 \mathrm{~m}$ below sea level.

Borehole information assembled by Bay Toll Crossings engineers consists of samples, hand specimen descriptions, stratigraphic cross sections, and the results of soil-mechanics tests. The samples, representing 20-50 percent of the drilled sediments, were collected in metal tubes $5-8 \mathrm{~cm}$ in diameter. Some samples were sealed in the tubes, whereas others were extruded and placed in glass jars. Many of the sealed tube samples were subsequently destroyed during laboratory tests. About 5,000 remaining tube and jar samples have been donated to the U.S. Geological Survey.

Most Bay Toll Crossings samples have changed during storage. Holocene estuarine deposits have undergone the most obvious alteration, including precipitation of gypsum and jarosite (Andrei SarnaWojcicki and Julius Schlocker, oral commun., 1974), 
replacement of framboidal pyrite by limonite, and color changes from gray to olive and brown. In addition, calcareous fossils may have dissolved in these sediments because of oxidation of pyrite or other reactions that increase the concentration of hydrogen ions. However, the common absence or decomposition of calcareous fossils in desiccated samples of Holocene estuarine deposits (such as in borehole 11 , section $A-A^{\prime}$, pl. 1 ) is probably due to dissolution prior to coring. This natural dissolution is evidenced by the absence of calcareous fossils in many of the fresh core samples we have collected from Holocene estuarine mud.

Sediments from 18 Bay Toll Crossings boreholes were examined for this study. Paleoecological interpretations are based in part on color, texture, authigenic mineralogy, bulk density or moisture content, and penetration resistance of sediments, and on megascopic plant and animal fossils. In addition, splits of about 175 samples from these boreholes were washed through sieves with a mesh opening of 0.063 $\mathrm{mm}$ for separation of foraminifers, ostracodes, diatoms, seeds, and microscopic authigenic minerals. Nearly all of these washed samples come from sediments less than $60 \mathrm{~m}$ below modern sea level, and most come from Holocene estuarine deposits. Finally, paleoecological interpretations were extrapolated to additional Bay Toll Crossings boreholes using the hand-specimen descriptions and physical properties recorded by the soils engineers.

Carbon-14 dates (pl. 1) were prepared with proportional gas counting techniques by Isotopes, Inc. Because of the small size of samples and the tendency of plant fragments to disintegrate when washed, carbon was obtained by burning entire sample splits rather than by concentrating plant fragments.

\section{LATE QUATERNARY DEPOSITIONAL HISTORY}

Numerous worldwide fluctuations of sea level during late Quaternary time are known from marineterrace and paleoclimatic records, but to date we have discerned only a few corresponding changes in depositional environment at the site of southern San Francisco Bay (fig. 2). Evidence of some fluctuations that are not presently recognized in sediments under the bay may have been removed by erosion. Evidence of others is probably contained in sediments located more than $60 \mathrm{~m}$ below sea level and not examined during this study.

\section{ESTUARINE DEPOSITS}

Deposits of the earliest known estuary situated in the vicinity of the present southern San Fran- cisco Bay contain a tuff approximately $1 \mathrm{~m} . \mathrm{y}$. (mil. lion years) old (table 1; Sarna-Wojcicki, 1976) and are consequently of early Pleistocene age. This earliest estuary probably connected with the Pacific Ocean via a shallow marine embayment at the site south of San Francisco in which sediments of the Merced Formation were deposited. These sediments were later deformed and uplifted. Freshwater drained to this estuary from the Great Valley, as evidenced by the presence of Great Valley detritus in a coeval part of the Merced Formation (Hall, 1966).

The youngest known estuarine deposits of Pleistocene age under southem San Francisco Bay were probably produced by Sangamon high stands of the sea. Although no unconformities have been recognized within the Sangamon estuarine deposits, the record of sea levels at New Guinea (fig. 2; Chappell, 1974, p. 568) suggests that the Sangamon estuary may have expanded and contracted several times in response to sea-level changes 70,000-130,000 years ago. The maximum areal extent of the Sangamon estuary was probably at least as great as that of the post-Wisconsin estuary because, despite postdepositional erosion, Sangamon estuarine deposits underlie most of the area of the post-Wisconsin estuarine deposits (pl. 1).

Data from the Atlantic continental shelf of the United States suggest that sea level approached its present height 30,000-40,000 years ago (middle Wisconsin) (Milliman and Emery, 1968). Estuarine sediments of this age appear to be absent under southern San Francisco Bay. Presumably, if the volume of estuarine deposits that would have accumulated at the site of southern San Francisco Bay during this high stand of sea level would be comparable to the volume that has accumulated during post-Wisconsin time, a considerable part of these middle Wisconsin estuarine sediments should have survived late Wisconsin erosion, as suggested by the preservation of large volumes of Sangamon estuarine deposits (pl. 1). Consequently, the apparent absence of middle Wisconsin estuarine deposits under southern San Francisco Bay indicates that local sea level did not approach its present height $30,000-40,000$ years ago. The improbability of a middle Wisconsin high stand of the sea in California has also been argued by Birkeland (1972, p. 446), who cited the general absence of post-Sangamon marine terraces in central and southern California.

Estuarine sediments have accumulated at the site of southern San Francisco Bay during the past 10,000 years in response to the post-Wisconsin sealevel rise. Representative fossils from these sediments are illustrated in figures 3 and 4 . 


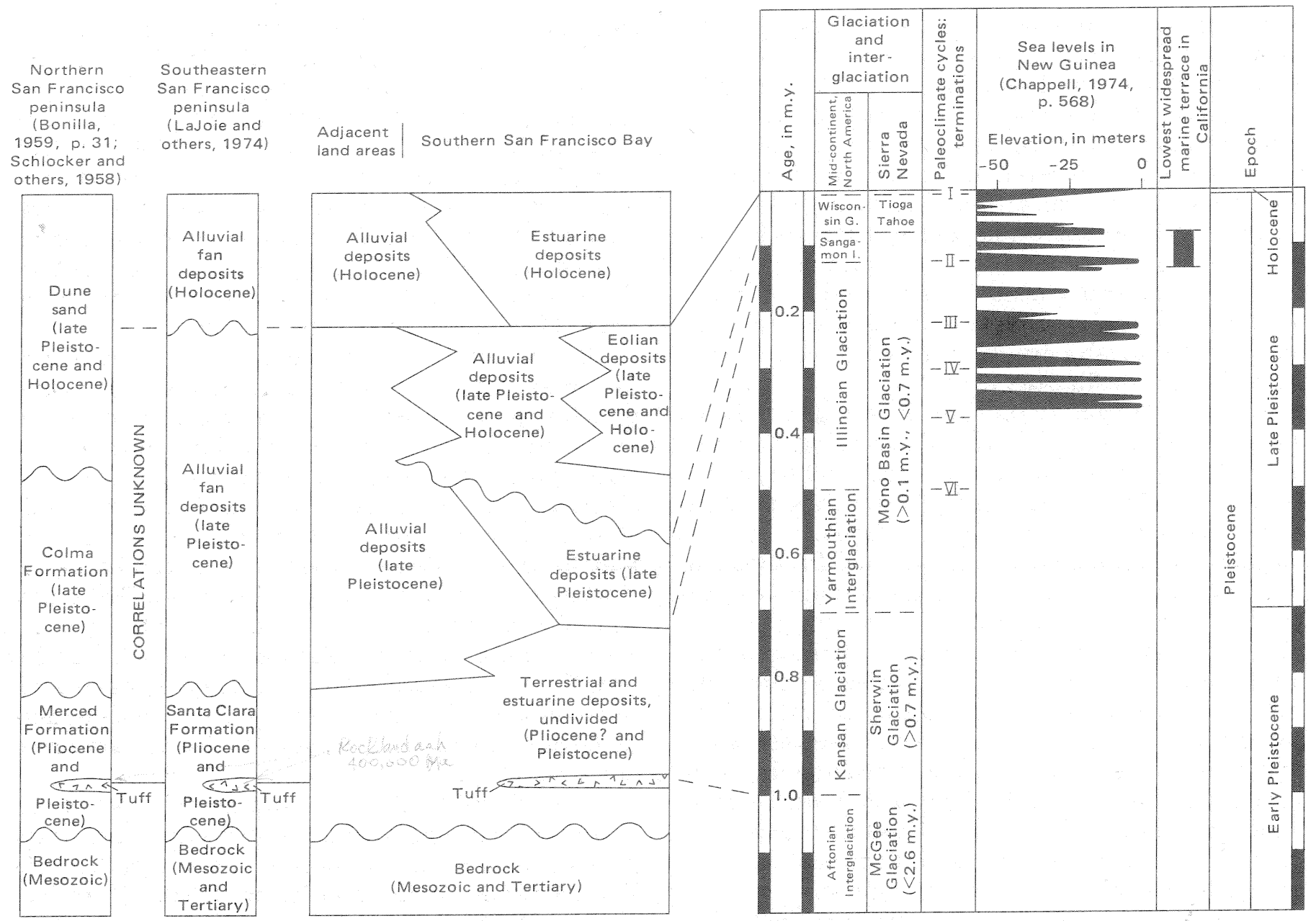

FrgURE 2,-Chronology for sediments under southern San Francisco Bay and their time-stratigraphic correlation with sediments of adjacent land areas, with late Quaternary glacial, climatic, and sea-level events, and with the lowest widespread marine terrace in California. Correlations are approximate where lines are dashed. Vertical scale of right side of main stratigraphic column is approximately proportional to thickness of units near borehole 2 (map, pl. 1). Wavy lines indicate unconformities, zig-zag lines indicate interfingering of time-equivalent units. Glacial chronology for mid-continental North America and epoch boundaries after Berggren and VanCouvering (1974, p. 144); glacial chronology for Sierra Nevada after Wahrhaftig and Birman (1965, p. 308, 331); paleoclimatic cycles from Broecker and VanDonk (1970, p. 181); age range of marine terrace from compilation by Birkeland (1972, p. 443). Correlation of tuff in type Merced Formation after Sarna-Wojcicki (1976). Radiometric ages of this tuff range from 0.4 to 2.6 m.y., but the most probable age is around 1.0 m.y. (A. Sarna-Wojcicki, written commun., 1975; see table 2).

\section{TERRESTRIAL DEPOSITS}

Estuarine deposits of different ages under southern San Francisco Bay are separated by alluvial and eolian sediments and by erosional unconformities and surfaces of nondeposition. These features indicate lowered base levels and oceanward migrations of the shoreline accompanying low stands of the sea.

Alluvial deposits of Wisconsin age under southern San Francisco Bay were not recognized by Louderback (1951, p. 87-88) and Treasher (1963, p. 24). These authors apparently mistook alluvial sediments for desiccated estuarine deposits. Presumably, the Sangamon estuarine deposits exposed at the Wisconsin land surface sustained oxidation, desiccation, leaching of calcareous fossils, and pene- tration by roots to a depth of several meters. Sediments between the Sangamon and post-Wisconsin estuarine deposits, however, average $15-25 \mathrm{~m}$ in thickness, contain much more sand and gravel than the adjacent estuarine deposits, and lack foraminifers, diatoms, and estuarine molluscs (pl. 1). Consequently, we interpret most of the Posey Formation of Trask and Rolston (1951) and much of the older bay mud of Treasher (1963) as alluvial deposits rather than desiccated estuarine sediments (fig. 5).

Eolian sands of Wisconsin age under southern San Francisco Bay were probably derived from flood. plains and beaches on the broad continental shelf that was exposed during low sea-level stands. These sands were transported across low-lying parts of San 
TABLE 1.-Description and interpretation of sediments and bedrock under southern San Francisco Bay

Color notations given according to the Munsell system

\begin{tabular}{|c|c|c|c|c|c|}
\hline Unit & Lithology & Stratigraphy & Abe & $\begin{array}{l}\text { Environment } \\
\text { of deposition }\end{array}$ & Correlations \\
\hline $\begin{array}{l}\text { Estuarine } \\
\text { deposita } \\
\text { (Holocene; } \\
\text { post. } \\
\text { Wisconsin). }\end{array}$ & 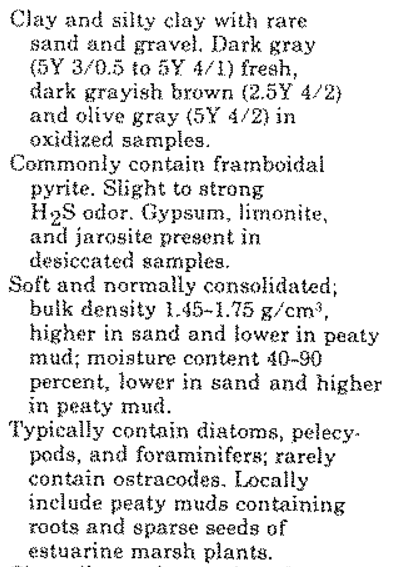 & $\begin{array}{l}\text { Cover stream } \\
\text { valleys, } \\
\text { alluvial fans, } \\
\text { and sand dunes } \\
\text { of latest } \\
\text { Pletistocene } \\
\text { (Wisconsin) and } \\
\text { early Holocene } \\
\text { age. Locally } \\
\text { interfinger } \\
\text { with late } \\
\text { Holocene allu. } \\
\text { vium at margins } \\
\text { of present } \\
\text { estuary. } \\
\text { Maximum thick. } \\
\text { ness about } 40 \mathrm{~m} \\
\text { over drowned } \\
\text { valleys near } \\
\text { San Francisco. }\end{array}$ & $\begin{array}{l}\text { Presently forming. Oldest } \\
\text { dated deposits approxi. } \\
\text { mately } 9 \text {,300 years ago; } \\
\text { oldest deposits near } \\
\text { Golden Gate, if pre- } \\
\text { served, probably } 10,000 \text { - } \\
11,000 \text { years ago. }\end{array}$ & $\begin{array}{l}\text { Ca. 9,500 years ago: small } \\
\text { brackish estuary extending } \\
\text { no further south than } \\
\text { Hunters Point. } \\
\text { Ca. } 9.500-7,000 \text { years ago: } \\
\text { rapidly enlarging } \\
\text { estuary, progressively } \\
\text { less diluted by fresh } \\
\text { water and locally fringed } \\
\text { by tidal marshes } \\
\text { Ca. } 7,000 \text { years ago to } 1850 \text { A.D. } \\
\text { slowly enlarginas estuary } \\
\text { with fringing salt marsheg } \\
\text { that have prograded during } \\
\text { the past several thousand } \\
\text { years. }\end{array}$ & $\begin{array}{l}\text { Equivalent to bay } \\
\text { mud of Trask and } \\
\text { Rolaton (1951) } \\
\text { and to normally } \\
\text { consolidated } \\
\text { member of } \\
\text { younger bay mud } \\
\text { of Treasher (1963, } \\
\text { p. } 15 \text { ). }\end{array}$ \\
\hline $\begin{array}{l}\text { Aluvial } \\
\text { deposits } \\
\text { (late Pleisto- } \\
\text { cene and } \\
\text { Holocene; } \\
\text { Wisconsin } \\
\text { in part). }\end{array}$ & 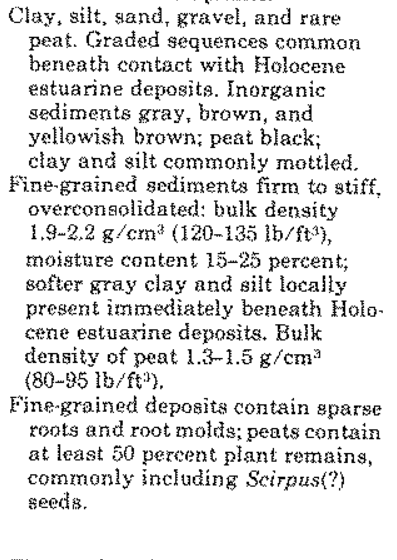 & $\begin{array}{l}\text { Disconformably } \\
\text { overlie } \\
\text { Sangamon(?) } \\
\text { estuarine } \\
\text { deposits. } \\
\text { Thickness } \\
\text { typically } \\
\text { increases } \\
\text { southeastward } \\
\text { from less than } \\
15 \text { m near San } \\
\text { Francisco to } \\
\text { more than } 25 \mathrm{~m} \\
\text { between Menlo } \\
\text { Park and tret. } \\
\text { mont (pl. } 1, \mathrm{C}^{\prime} \text { ). }\end{array}$ & $\begin{array}{l}\text { Oldest deposits over } 40,000 \\
\text { years old but probably } \\
\text { legs than } 100,000 \text { years } \\
\text { old. Include late Holo- } \\
\text { cene deposits under max. } \\
\text { gins of southern San } \\
\text { Francisco Bay. }\end{array}$ & $\begin{array}{l}\text { Alluvial fans and trunk strean } \\
\text { of yalley now occupied by } \\
\text { gouthem San Francisco Bay } \\
\text { eqtuary. Trunk stream was a } \\
\text { tributary to ancestral San } \\
\text { Joaquin-Sacramento Rivers. } \\
\text { Peats immediately beneath } \\
\text { Holocene estuarine deposits } \\
\text { near San Francisco record } \\
\text { freshwater-marsh conditions } \\
\text { in valleys that were probably } \\
\text { ponded as bage levels rose } \\
\text { rapidly in response to early } \\
\text { Holocene sea-level changes. }\end{array}$ & $\begin{array}{l}\text { Coeval with } \\
\text { Holocene and } \\
\text { late Pleistocene } \\
\text { alluvial fan } \\
\text { deposits of } \\
\text { Helley, Lajoie, } \\
\text { and Burke (1972), } \\
\text { Include Pogey For. } \\
\text { xation of Trask } \\
\text { and Rolston (1951), } \\
\text { some basal peat in } \\
\text { bay mud of Trask } \\
\text { and Roleton (1951), } \\
\text { preconsolidated } \\
\text { member of } \\
\text { younger bay mud } \\
\text { of Treasher (1963, } \\
\text { p. } 15 \text {, and part of } \\
\text { sand deposits and } \\
\text { bay nud of } \\
\text { Treasher (1963, } \\
\text { p. 15). }\end{array}$ \\
\hline $\begin{array}{l}\text { Eolian } \\
\text { deposits (late } \\
\text { Pleistocene } \\
\text { and Holocene; } \\
\text { Wisconsin } \\
\text { in part). }\end{array}$ & $\begin{array}{l}\text { Fine-and medium-gratined sand } \\
\text { with subordinate silt. Sand grains } \\
\text { angular to rounded, mainly sub. } \\
\text { rounded and rounded. Yellowish } \\
\text { brown, dark grayish brown } \\
(2.5 Y 4 / 2) \text {, and olivegray }(5 \mathrm{Y} \text { 4/2.5). } \\
\text { Bulk density } 1.9-2.2 \mathrm{~g} / \mathrm{cm}^{3} \text {, moisture } \\
\text { content } 15-25 \text { percent. } \\
\text { Remains of burrowing estuarine } \\
\text { invertebrates locally present at } \\
\text { contact with Holocene egtuarine } \\
\text { deposits. }\end{array}$ & $\begin{array}{l}\text { Overlie and locally } \\
\text { may interfinger } \\
\text { with Wisconsin } \\
\text { alluvial deposits. } \\
\text { probably extend } \\
\text { southeastward from } \\
\text { Calden Gate to the } \\
\text { vicinity of San } \\
\text { Mateo (pl. 1, map). } \\
\text { Maximum thick } \\
\text { ness, near Oak- } \\
\text { land, at Jeast } 15 \mathrm{~m} \\
\text { (Trask and } \\
\text { Rolwton, } 195 \mathrm{~s}, \\
\text { p. 1104). }\end{array}$ & $\begin{array}{l}\text { Overlie peaty sediments } \\
\text { oldex than } 40,000 \text { years in } \\
\left.\text { borehole } 7(p) .1, A-A^{*}\right) \\
\text { therefore, oldest eolian } \\
\text { deposits may be over } \\
40,000 \text { years old. Deposi- } \\
\text { tion may have persisted } \\
\text { into bolocene time, but } \\
\text { most eolian deposits prob- } \\
\text { ably accumulated during } \\
\text { latest Pleistocene (Wiscon. } \\
\text { ain) trme. }\end{array}$ & 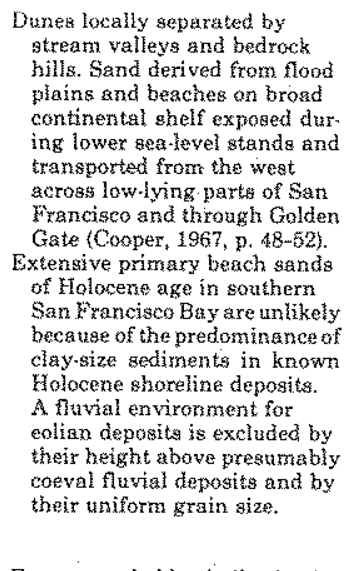 & $\begin{array}{l}\text { Lithologically } \\
\text { correlative and } \\
\text { probably coeval } \\
\text { with some of } \\
\text { extensive dune } \\
\text { sands in San } \\
\text { Francisco } \\
\text { (Cooper, 1967; } \\
\text { Schlocker and } \\
\text { others, } 1958 \text {; } \\
\text { Bonilla, 1965) and } \\
\text { with the Merritt } \\
\text { Sand in Onkland } \\
\text { (1) woon, 1914, } \\
\text { y. } 15 \text { ). } \\
\text { Equivalent to most } \\
\text { of the Merrits } \\
\text { Sand of Trask and } \\
\text { Rolston (1951) and } \\
\text { to some of the sand } \\
\text { deposits of } \\
\text { Treasher (1963, } \\
\text { p. } 15 \text { ). }\end{array}$ \\
\hline $\begin{array}{l}\text { Estuarine } \\
\text { deposits (ate } \\
\text { Pleistocene; } \\
\text { Sangamon). }\end{array}$ & 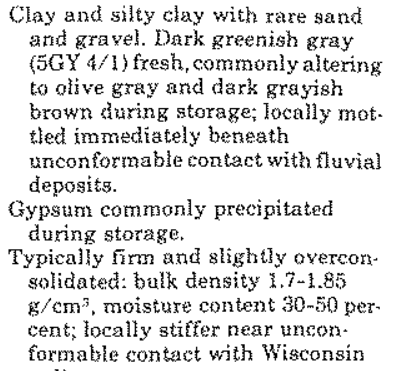 & $\begin{array}{l}\text { Overlie pre- } \\
\text { Sangstnon tertes- } \\
\text { trial deposits. } \\
\text { Maximum } \\
\text { thickness } \\
\text { approximately } \\
30 \mathrm{~m} \text {. }\end{array}$ & $\begin{array}{l}\text { Disconformably overlain by } \\
\text { terrestrial deposits over } \\
40,000 \text { years old in bore- } \\
\text { hole } 7 \text { (pl. } 1 A-A^{\prime} \text { ), therefore } \\
\text { older than } 40,000 \text { years. } \\
\text { Separated from underlying } \\
\text { tuff of Merced Formation } \\
\text { (1.110.4 m.y.old) by at least } \\
20 \text { m of alluvial sediments } \\
\text { and at least one major } \\
\text { unconformity in borehole } 2 \\
\text { (location of this borehole } \\
\text { shown on map, pl. } 1 \text { ). }\end{array}$ & $\begin{array}{l}\text { Estuary probably similat in size } \\
\text { and shape to the Holocene San } \\
\text { Francisco Bay. } \\
\text { Water depths of at least } 20-40 \mathrm{~m} \\
\text { near mouth of estuary indi- } \\
\text { cated by molluscan assera. } \\
\text { blage east of Yerba Buens } \\
\text { lstand (W. O. Addicott, written } \\
\text { comm., } 1973 \text {; sample eleva- } \\
\text { tion } 45 \mathrm{~m} \text { below present sea } \\
\text { level). }\end{array}$ & $\begin{array}{l}\text { Probably coeval } \\
\text { with the lowest } \\
\text { widespread } \\
\text { marine terrace of } \\
\text { comstal Californis } \\
\text { (fig. 2) and with } \\
\text { some of the late } \\
\text { pleistocene } \\
\text { alluvial fan deposits } \\
\text { of Helley, Lajoie, } \\
\text { and Burke (1972). } \\
\text { lnclude most of the } \\
\text { San Antomio } \\
\text { Formation. }\end{array}$ \\
\hline
\end{tabular}


Table 1.-Description and interpretation of sediments and bedrock under San Francisco Bay-... Continued

\begin{tabular}{|c|c|c|c|c|c|}
\hline Unit & Lithology & Stratizraphy & Agte & $\begin{array}{l}\text { Environment } \\
\text { of deposition }\end{array}$ & Correlations \\
\hline $\begin{array}{l}\text { Estuarine } \\
\text { deponitg (late } \\
\text { Eleistocene; } \\
\text { Sangamon)- } \\
\text { Continued }\end{array}$ & $\begin{array}{l}\text { Commonly contain estuarine dia. } \\
\text { toms, pelecypods, and foraminifers } \\
\text { similar to those in Holocene } \\
\text { deposits. Locally include yeaty } \\
\text { clays near contact with older teres. } \\
\text { trial deposits. }\end{array}$ & & $\begin{array}{l}\text { Represent the youngest } \\
\text { major Pleistocene high } \\
\text { sealevel stand, as shown } \\
\text { by their great extent and } \\
\text { thickness and by the } \\
\text { apparent absence of over. } \\
\text { lying pre-Holocene eatu- } \\
\text { arine deposits. Therefore } \\
\text { correlated with the } \\
\text { Sangamon Interglaciation } \\
\text { and regarded as } 75,000- \\
125,000 \text { years old. }\end{array}$ & & \\
\hline 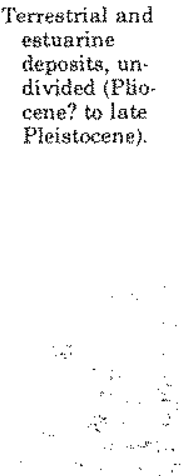 & $\begin{array}{l}\text { Clay, silt, sand, and gravel. } \\
\text { Estuarine deposits contain sparse } \\
\text { mollusks, foraminifers, ostra- } \\
\text { codes, and diatoms and include a } \\
\text { tuff } 87 \mathrm{~m} \text { below present sea level in } \\
\text { borehole } 2 \text { (location of this borehole } \\
\text { shown on map, pl. 1). This tuff cor } \\
\text { relates with a tuff in the type } \\
\text { Merced Formation (Sarna- } \\
\text { Wojcick, } 1976 \text { ). }\end{array}$ & $\begin{array}{l}\text { Unconformably } \\
\text { overtie Mesozoic } \\
\text { and Tertiary(?) } \\
\text { rocks. Extend at } \\
\text { least } 130 \mathrm{~m} \text { below } \\
\text { gea level east of } \\
\text { Yerba Buena } \\
\text { Lsland (Trask } \\
\text { and Rolston, } 1951, \\
\text { p. } 1081 \text { ) and at } \\
\text { least } 200 \mathrm{~m} \text { below } \\
\text { sea level in } B-B^{\prime} \\
\text { and } C C^{\prime} \text { (pl. l) } \\
\text { (Finlayson and } \\
\text { others, } 1967, \text { pl. } 5 \text {; } \\
\text { Meade, } 1967, . . \\
\text { p. } 40-41) .\end{array}$ & 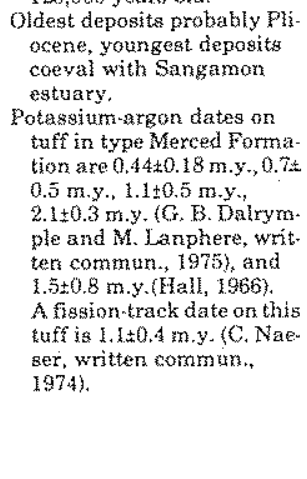 & $\begin{array}{l}\text { Basing subjected to oscillating } \\
\text { sea levels and modified by tec- } \\
\text { tonic processes. Basing of } \\
\text { about i m.y. ago distupted by } \\
\text { later folding and faulting } \\
\text { (Lajoie and others, 1974). }\end{array}$ & $\begin{array}{l}\text { Pliocent(?) and } \\
\text { early Pleistocent } \\
\text { sediments coeval } \\
\text { with Merced and } \\
\text { Santa Clara Form- } \\
\text { ationg. Younger } \\
\text { sediments } \\
\text { possibly coeval } \\
\text { with some of late } \\
\text { Pleistocene allu- } \\
\text { viral fandeposits of } \\
\text { Helley, Lajode, and } \\
\text { Burke (1972). } \\
\text { Equivalent to parts } \\
\text { of Alameda Forma. } \\
\text { tion (Trask and } \\
\text { Rolston, } 1951 \text { ) and } \\
\text { older hay mud of } \\
\text { Treasher (1963, p. 15) }\end{array}$ \\
\hline 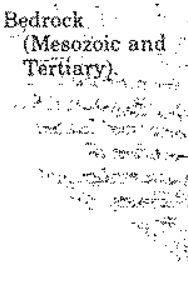 & $\begin{array}{l}\text { Predominantly clastic sedimentary } \\
\text { rocks and igneotas rocks, in part } \\
\text { altered by low-temperature } \\
\text { metrmorphism. } \\
\therefore\end{array}$ & $\begin{array}{l}\text { Late Mesozoic Frano } \\
\text { can rocks and gerp } \\
\text { form the known at } \\
\text { phic and structura } \\
\text { ment. Althoush di } \\
\text { overlain by Quate } \\
\text { deposita near San } \\
\text { cisco, Franciscan } \\
\text { may be mantled b. } \\
\text { Mesozoic or Tertia } \\
\text { under other parts } \\
\text { San Francisco Bay }\end{array}$ & $\begin{array}{l}\text { tinite } \\
\text { tigre. } \\
\text { ase. } \\
\text { tyy } \\
\text { ary } \\
\text { an- } \\
\text { ks } \\
\text { ther } \\
\text { rocks } \\
\text { gothern }\end{array}$ & $\begin{array}{l}\text { These rocks formed in } \\
\text { various ancient marne, } \\
\text { continental, and plutonic } \\
\text { environments that were } \\
\text { subsequently destroyed by } \\
\text { crustal movement. }\end{array}$ & \\
\hline
\end{tabular}

Francisco by prevailing westerly winds (Cooper, 1967, p. 48-52).

The lowest base level at the Golden Gate during Wisconsin time was probably about $70 \mathrm{~m}$ below present sea level. This base level is suggested by bedrock sills located about $5 \mathrm{~km}$ east and northeast of the Golden Gate, the lowest of which is $65 \mathrm{~m}$ below present sea level (Carlson and McCulloch, 1970). Consequently, assuming that sea level during the late Wisconsin glacial maximum stood about $100 \mathrm{~m}$ below present sea level (Flint, 1971, p. 322), the late Wisconsin shoreline must have been located west of the Golden Gate on what is now the continental shelf (fig. 1).

Plant fossils dated at 23,600 years old and found $10 \mathrm{~km}$ southeast of Menlo Park (map, pl. 1) about $8 \mathrm{~m}$ below present sea level show a relative abundance of cedar and Douglas fir and a relative scarcity of oak and redwood, thus suggesting a cooler, wetter climate than today (David P. Adam, oral commun., 1973). Associated animal fossils indicate that Rancholabrean vertebrates, including camels, bison, horses, sloths, and mammoths, roamed the late Wisconsin valley now occupied by southern San Francisco Bay (Edward J. Helley and Kenneth R. Lajoie, unpub. data).

\section{HOLOCENE SEA LEVELS}

\section{RELATION OF DATLD SAMPLES TO FORMER SEA LEVELS}

Holocene sea levels are typically dated by the radiocarbon ages of plant or animal remains that initially accumulated near sea level. The roots of salt-marsh plants are the principal materials dated for this study and represent upper intertidal conditions. Additional control on the age of former sea levels is given by dated plant remains from intertidal or uppermost subtidal environments and from predominantly freshwater marsh environments at or above the highest tides (table 2).

\section{SALT-MARSH DEPOSITS}

With the possible exception of elgrass (Zostera), an aquatic plant which is very rare or absent in San Erancisco Bay today, plants which inhabit salt marshes are the only ones that can produce peaty estuarine muds composed largely of roots in growth positions. Therefore the principal feature of saltmarsh deposits that differentiates them from other estuarine sediments is the abundance of roots in growth positions. Additional diagnostic characteristics of salt-marsh deposits include a typical abundance of arenaceous foraminifers, a scarcity or 

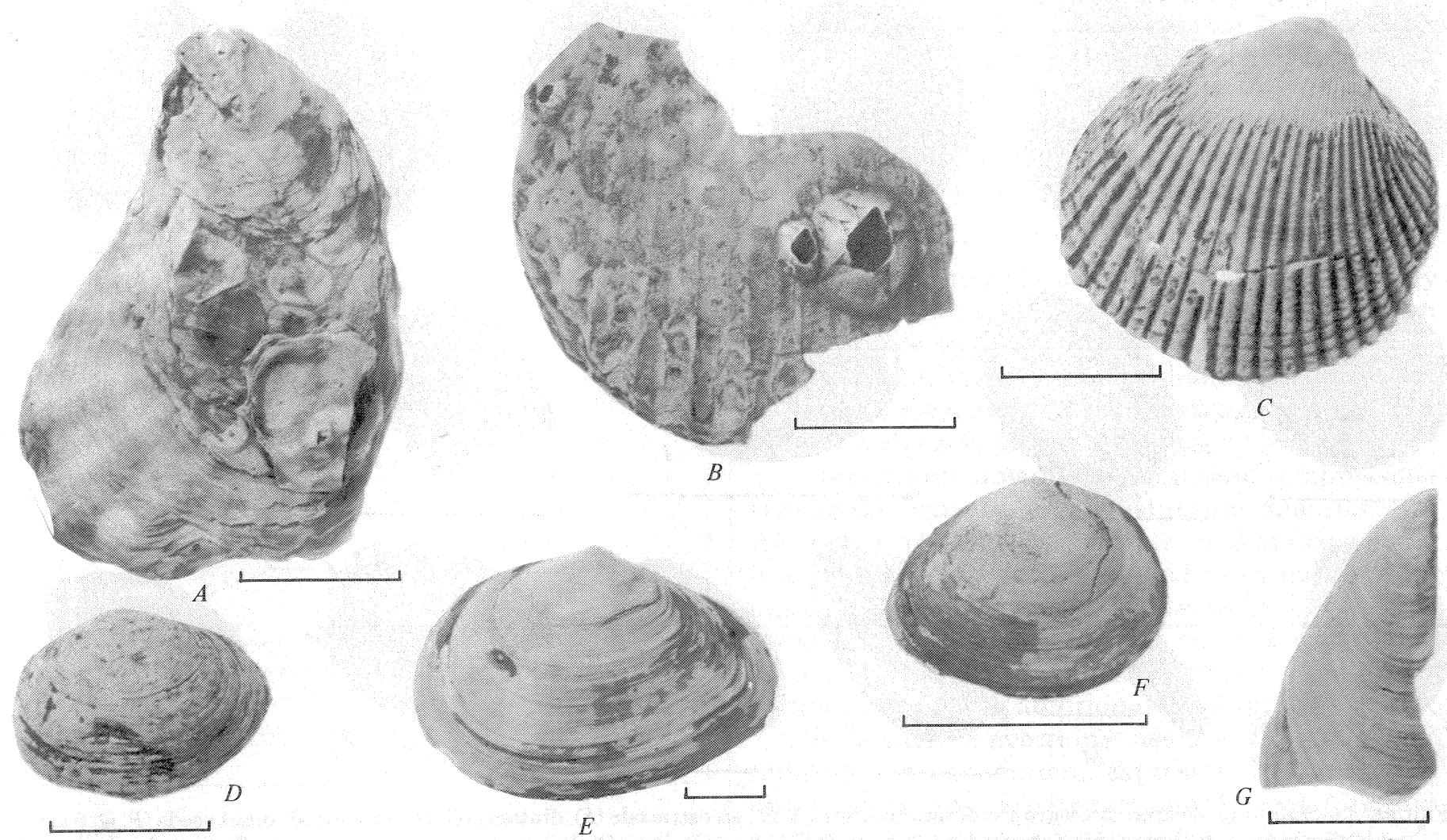

FIGURE 3.-Representative pelecypods from post-Wisconsin estuarine sediments under southern San Francisco Bay. Scale bar represents $1 \mathrm{~cm}$. A, Ostrea lurida Carpenter; B, Balanus sp. (barnacle) attached to a fragment of Clinocardium cf. C. nuttalli (Conrad); C, Clinocardium nuttalli (Conrad); D, Cryptomya californica (Conrad); E, Macoma nasuta (Conrad); $F$, Macoma balthica (Linné); G, Mytilus edulis (Linné), fragment.

absence of calcareous fossils (Phleger, 1970, p. 532$533)$, and a local abundance of framboidal pyrite and insect remains (table 2).

The salt-marsh deposits used to date sea-level changes were collected at or slightly above the contact between Holocene estuarine deposits and underlying terrestrial sediments, thereby minimizing uncertainties due to postdepositional compaction and settlement. By analogy with the historic salt marshes of southern San Francisco Bay (Hinde, 1951, p. 219; Nichols and Wright, 1971; map, pl. 1), these basal salt-marsh deposits accumulated in the upper intertidal zone at the fringes of the estuary, but at lower sea levels than today. Most of these marshes were eventually submerged by the rising sea as evidenced by the common overlapping of basal saltmarsh deposits by lower intertidal and subtidal sediments.

Salt-marsh deposits were not sampled near the base of Holocene estuarine deposits in some Bay Toll Crossings boreholes, such as numbers $6,7,18,24,29$, and 39 (pl. 1). The apparent absence of basal saltmarsh deposits in these boreholes may be explained in part by gaps between core samples. No basal marsh deposits were found, however, in boreholes 13 and 26-29 (pl. 1), in which basal estuarine sediments were carefully sampled. Collectively, this evidence suggests that salt-marsh plants may have been unable to colonize stretches of Holocene shorelines because the rate of relative sea-level rise exceeded local rates of sedimentation (Bloom, 1967a, p. 36), or that salt-marsh deposits submerged by rising Holocene sea levels may have been locally removed by wave erosion.

$$
\text { INTERTIDAL AND UPPERMOST SUBTIDAL DEPOSITS }
$$

Estuarine sediments lacking roots in growth positions, containing shallow-water calcareous fossils, and resting on alluvial or eolian deposits probably accumulated in intertidal or uppermost subtidal environments. The plant remains in these sediments are regarded as detrital.

\section{FRESHWATER MARSH DEPOSITS}

Sediments composed dominantly of plant remains, containing Scirpus? seeds, and lacking foraminifers and diatoms larger than $0.063 \mathrm{~mm}$ are found immediately beneath Holocene estuarine deposits in buried Wisconsin valleys near San Francisco at elevations between -25 and $-45 \mathrm{~m}\left(A-A^{\prime}\right.$, pl. 1; Calif. Div. Bay Toll Crossings, 1966, and unpub. cross sections, 1970). These sediments probably accumulated in marshes located at or above the highest tides. Freshwater marsh deposits do not appear to underlie Holocene estuarine sediments between San 

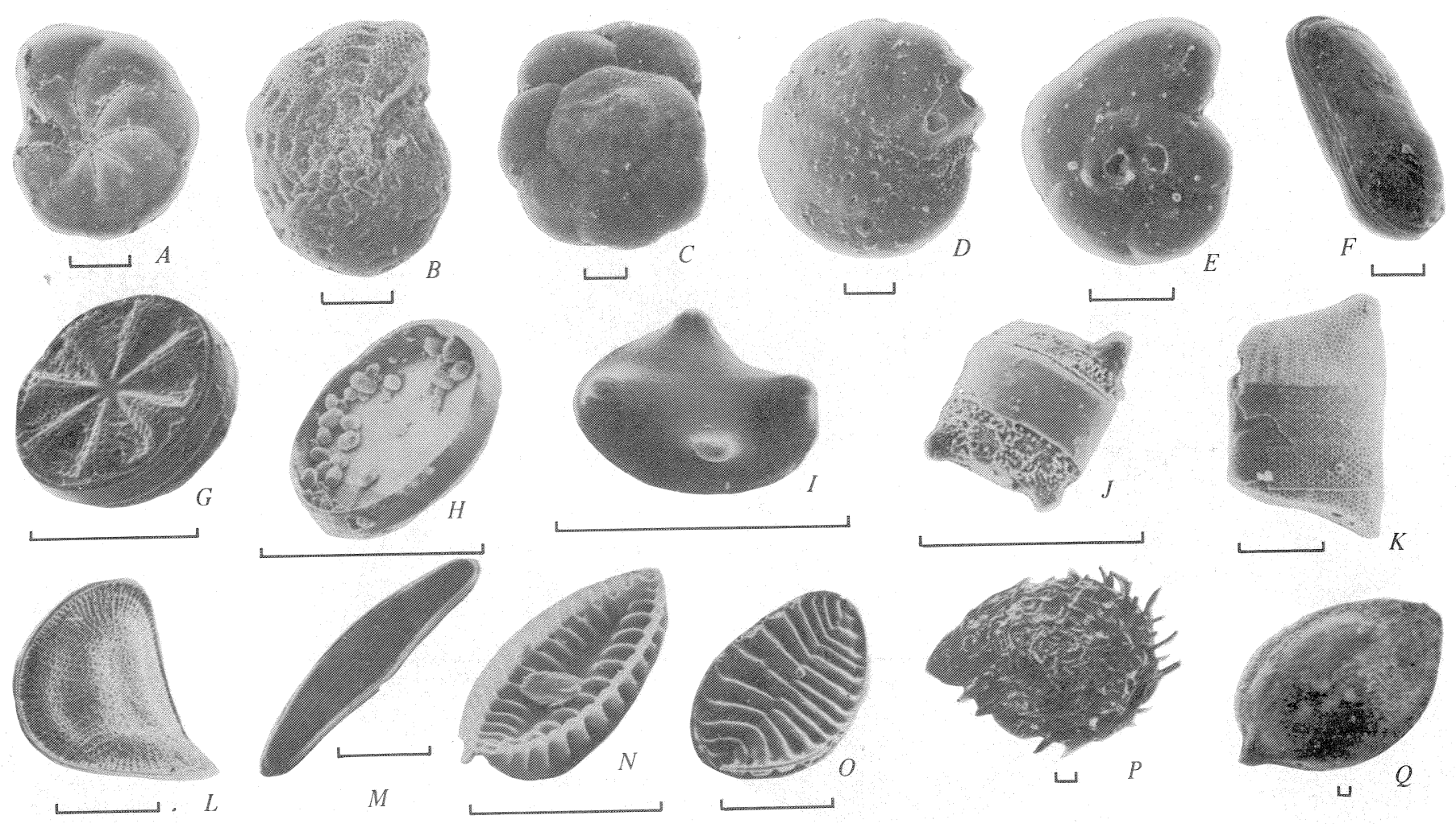

FIGURE 4.-Scanning electron micrographs of foraminifers $(A-E)$, an ostracode $(F)$, diatoms $(G-O)$, and marsh-plant seeds $(P, Q)$ from post-Wisconsin estuarine sediments under southern San Francisco Bay. Scale bar represents $0.1 \mathrm{~mm}$. A, Elphidium incertum obscurum (Williamson) var. obscurum Voloshinova; $B$, Elphidium gunteri Cole; $C$, Ammonia beccarii (Linné); $D$, Elphidiella hannai (Cushman and Grant); E, Trochammina inflata (Montagu); F, Cytheromorpha sp.; G, Actinoptychus splendens (Shadbolt) Ralfs; H, Coscinodiscus sp. (note framboidal pyrite in frustule); I, Aulacodiscus kittoni Arnott; J. Biddulphia sp.; K, Isthmia nervosa Kützing; L, Campylodiscus sp.; M, Cymbella cf. C. aspera (Ehrenberg) Cleve; N, Surirella sp.; O, Surirella? sp.; $P$, Salicornia sp.; Q, Scirpus? sp.

Mateo and Hayward and between Menlo Park and Fremont (sections $B-B^{\prime}$ and $C-C^{\prime}, \mathrm{pl} .1$ ).

\section{NUMERICAL UNCERTAINTIES IN SEA-LEVEL DATA}

The 100-320-year uncertainties in the ${ }^{14} \mathrm{C}$ ages of Holocene sea levels (table 2) incorporate laboratory errors only. Other possible errors are difficult to estimate. The possibility of contamination of saltmarsh deposits by roots of younger marsh plants (Kaye and Barghoorn, 1964, p. 72) is ignored because the resultant decrease in sample age is probably no greater than a few centuries under conditions of rising sea level. The error caused by the time gap between death of plant material and its final accumulation as detritus is also ignored except in borehole 17 (section $B-B^{\prime}$, pl. 1), where detrital wood must be regarded as reworked fossil material because it is several thousand years older than the associated estuarine sediments.

The elevations of Holocene sea levels are determined by the equation

$$
H=h-h_{O}+s \text {, }
$$

where $H$ is the elevation of a former sea level, $h$ is the modern sample elevation, $h_{o}$ is the sample elevation at the time of deposition, and $s$ is the postdepositional subsidence of the sample. Measured and estimated errors contributed by these factors typically total $\pm 2- \pm 4 \mathrm{~m}$ in this study.

\section{MODERN SAMPLE ELEVATION $(h)$}

The uncertainty in modern sample elevation (table 2) is the approximate sum of errors in (1) the elevation of the top of the borehole, (2) the depth of the sample interval within the borehole, and (3) the position of the dated sample within the sample interval. This uncertainty averages about $\pm 0.5 \mathrm{~m}$ and does not exceed $\pm 1.0 \mathrm{~m}$.

\section{SAMPLE ELEVATION AT TIME OF DEPOSITION $\left(h_{0}\right)$}

The elevation ranges of modern salt-marsh plants approximate the elevations at which Holocene salt-marsh deposits accumulated. The lowest natural surfaces of tidal marshes in the San Francisco Bay estuary are located about $0.5 \mathrm{~m}$ below mean sea level and are colonized by cordgrass 


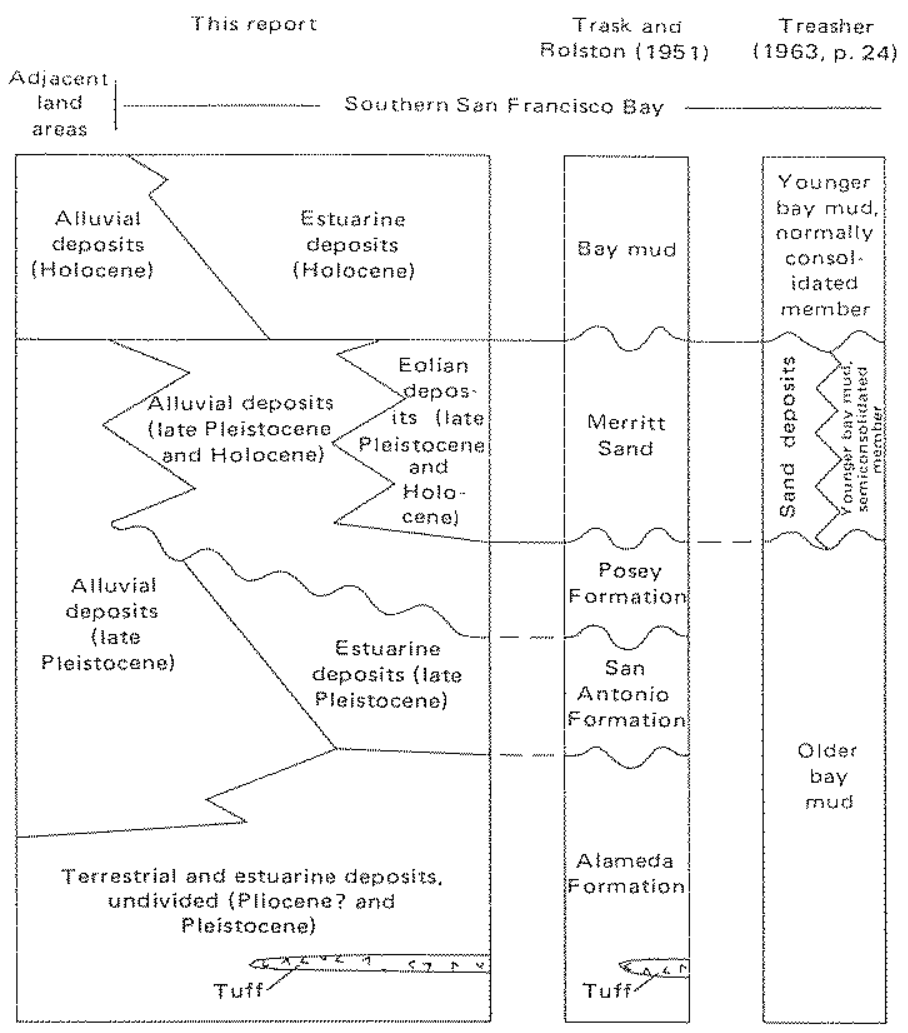

Frgure 5.-Comparison of stratigraphic nomenclature for sediments under southern San Francisco Bay. Wavy lines indicate unconformities; zig-zag lines indicate interfingering of time-equivalent units. Lines between columns correlate rock. stratigraphic units and are dashed where correlations are approximate.

(Spartina foliosa) or tules (predominantly Scirpus californicus). These large plants are replaced by smaller plants, predominantly pickleweed (Salicornia pacifica) and salt grass (Distichlis spicata), at elevations greater than $0.5-1.0 \mathrm{~m}$ above mean sea level (Hinde, 1954; Atwater and Hedel, 1976). The highest elevation of abundant Salicornia and Distichlis approximately equals that of the highest tides, varies geographically with local tidal amplification, and ranges from about $1.5 \mathrm{~m}$ above mean sea level near San Francisco to about $2.0 \mathrm{~m}$ above mean sea level near Menlo Park.

Although plant remains have not been positively identified, most of the dated tidal-marsh deposits appear to contain the small roots and rhizomes of high-marsh plants (Salicomia and Distichlis) rather than the robust rhizomes of lowmarsh plants (Spartina and Scirpus). These dated roots and rhizomes probably penetrated a few decimeters below the surfaces of the marshes. Consequently, most of the dated salt-marsh plant remains probably accumulated about $0-1.5$ to $0-2.0$ $m$ above former mean sea levels, the upper limit varying with local tidal range (table 2 ).

The paleobathymetry of the dated intertidal or uppermost subtidal deposits has an uncertainty of $\pm 1.5 \mathrm{~m}$. Freshwater marsh deposits provide only upper limits on the elevation of sea level at the time of their accumulation (table 3 ).

\section{POSTDEPOSITONAL SUBSIDENCE (S)}

Postdepositional subsidence (table 2) is likely where sediment overburden has placed a load on compressible sediments beneath the dated samples. Errors in thickness and consolidation of the compressible sediments lead to uncertainties as large as $\pm 2.5 \mathrm{~m}$ in the subsidence estimates.

Uncertainty about the thickness of compressible sediments beneath dated estuarine deposits and freshwater peats results from 1 - to 3 -m discontinuities in sampling between dated horizons and the underlying noncompressible terrestrial deposits. Typically, the location of the contact within the discontinuity is unknown and cannot be determined without very costly additional drilling.

Settlement corrections assume the following ranges of consolidation, expressed in percent of initial thickness: freshwater-marsh peat (organic matter content probably greater than 50 percent), 15 40; salt-marsh mud (organic matter content probably less than 25 percent), 33-67; nonmarsh estuarine mud, 40-80; and soft alluvial clay within $5 \mathrm{~m}$ of the dated sample, 80-100. These estimates are based on the following data: (1) fresh water peat buried by $3-10$ $m$ of Holocene estuarine mud for 1,000-6,000 years in Connecticut has been compressed to $13-44$ percent of its initial thickness (Bloom, 1964, p. 603) and (2) a column of mud with an initial porosity of 80 percent, an initial thickness of $3 \mathrm{~m}$, and an overburden of $30 \mathrm{~m}$ will theoretically compress to 50 percent of its initial thickness (Weller, 1959, p. 290).

The settlement corrections generally neglect compaction of Pleistocene estuarine deposits and stiff or coarse-grained terrestrial sediments. Between Menlo Park and Fremont, however, they include about $0.5 \mathrm{~m}$ of compaction of Pleistocene clay due to ground water withdrawal (Poland, 1971). Repeated leveling around the margins of southern San Francisco Bay by the U.S. Geological Survey and the U.S. Coast and Geodetic Survey suggests that this historic land subsidence dwindles north. west of Menlo Park and Fremont.

\section{THE HOLOCENE TRANSGRESSION}

The small quantity and large uncertainties of sea-level data prevent resolution of low- 
TABLE 2.-Data on Holocene sea levels

[All linear measurements in meters; see plate 1 for location of boreholes]

\begin{tabular}{|c|c|c|c|c|c|c|c|c|c|c|c|c|}
\hline \multirow{3}{*}{$\begin{array}{l}\text { Bors. } \\
\text { hole No. }\end{array}$} & \multirow{3}{*}{$\begin{array}{l}\text { Sample } \\
\text { elevation } \\
\text { relative } \\
\text { to modern } \\
\text { mean sea } \\
\text { level }(h)\end{array}$} & \multirow{3}{*}{$\begin{array}{l}\text { Principal } \\
\text { dated } \\
\text { material }\end{array}$} & \multirow{3}{*}{$\begin{array}{l}\text { Environmental } \\
\text { indicators? }\end{array}$} & \multirow{3}{*}{$\begin{array}{l}\text { Sample } \\
\text { elevation } \\
\text { at time of } \\
\text { depogition } \\
\text { relative } \\
\text { to former } \\
\text { mean gea } \\
\text { level }\left(h_{o}\right)^{2}\end{array}$} & \multicolumn{6}{|c|}{$\begin{array}{l}\text { Postdepositional subsidence (s) of dated sample caused } \\
\text { by compaction of underlying sediments } \\
\mathrm{T} \text { = thickness of compressible sediments } \\
\mathrm{S}=\text { settlement }\end{array}$} & \multirow{3}{*}{$\begin{array}{l}\text { Elevation of } \\
\text { mean sea } \\
\text { level at } \\
\text { time of ac- } \\
\text { cumulation } \\
\text { of dated } \\
\text { material } \\
\text { relative to } \\
\text { modern } \\
\text { mean sea } \\
\text { level }(\bar{H})\end{array}$} & \multirow{3}{*}{$\begin{array}{l}\text { Age and } \\
\text { analytical } \\
\text { uncer } \\
\text { tainty in } \\
\text { "C years } \\
\text { before } \\
\text { 1950 A.D. } \\
\text { (half life } \\
\text { w5,568 } \\
\text { years) } \\
\text { (see pl. } 1 \text { ) }\end{array}$} \\
\hline & & & & & \multicolumn{2}{|r|}{$\begin{array}{l}\text { Holocene } \\
\text { eatuarine } \\
\text { deposits }\end{array}$} & \multicolumn{2}{|c|}{$\begin{array}{l}\text { Late Pleistocene } \\
\text { and Holocene } \\
\text { terrestrial } \\
\text { deposits }\end{array}$} & \multicolumn{2}{|c|}{$\begin{array}{l}\text { Pleistocene } \\
\text { deposits, } \\
\text { groundwater } \\
\text { withdrawal } \\
\text { (Poland, 1971) }\end{array}$} & & \\
\hline & & & & & $\mathrm{T}$ & $\mathrm{S}$ & $T$ & $\mathrm{~S}$ & $\$$ & Totakl s & & \\
\hline 35 & $-7.9 \pm 0.5$ & $\begin{array}{l}\text { Roots of } \\
\text { anlt } \\
\text { marsh } \\
\text { plants. }\end{array}$ & $\begin{array}{l}\text { Abundant rootz, prob- } \\
\text { ably in growth } \\
\text { positions; Trocham- } \\
\text { mina inflata (Fa); } \\
\text { Campylodiscus (Dp). }\end{array}$ & $1.0+1.0$ & 2.0 & $0.5-3.0$ & $0.0-1.5$ & $0.0-0.4$ & $0.3-0.7$ & $2.4 \div 1.6$ & $-6.5 \pm 3.1$ & $3,360 \pm 106$ \\
\hline 23 & $-6.6 \pm 0.3$ & $\begin{array}{l}\text { Fragments } \\
\text { of salt. } \\
\text { marsh } \\
\text { plants. }\end{array}$ & $\begin{array}{l}\text { Abundant plant frag- } \\
\text { ments, probably } \\
\text { detrital, and Sali. } \\
\text { comia seeds }(A, s) ; \\
\text { Etphialium spp. (Fo); } \\
\text { Ostrea lurida }(P, s) ; \\
\text { shells broken and } \\
\text { probably detrital }\end{array}$ & $-0.5 \pm 1.5$ & $0.3-1.0$ & $0.1-1.5$ & 0 & 0 & 0 & $0.8 \pm 0.7$ & $-5.3+2.5$ & $3,930 \pm 165$ \\
\hline $36^{3}$ & $-9.0 \pm 0.3$ & $\begin{array}{l}\text { Roots of } \\
\text { salt } \\
\text { marah } \\
\text { plants. }\end{array}$ & $\begin{array}{l}\text { Aburdant roots, prot. } \\
\text { ably in growth } \\
\text { positions; Tracham- } \\
\text { mina inflata (Fa); } \\
\text { framboidal pyrite. }\end{array}$ & $1.0+1.0$ & $0.0-2.0$ & $0.0-3.0$ & $2.0-3.0$ & $0.0-0.8$ & $0.3-0.7$ & $2.4 \pm 2.1$ & -7.643 .4 & $5,745 \pm 185$ \\
\hline 32 & $-11,4 \pm 0.5$ & - ndo & $\begin{array}{l}\text { Abundant roots, prob- } \\
\text { ably in growth } \\
\text { positions; Trocham- } \\
\text { mina inflata (Fa); } \\
\text { Campylodiscus (Dp). }\end{array}$ & $1.0 \pm 1.0$ & $0.0-1.0$ & $0.0-2.0$ & $0.0-1.0$ & $0.0-0.3$ & $0.3-0.7$ & $1.6 \pm 1.3$ & $-10.8 \pm 2.8$ & $5,845 \pm 100$ \\
\hline 33 & $-10.8+0.5$ & $\cdots$ dom.n. & 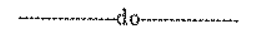 & $1.0 \pm 1.0$ & $0.0-1.0$ & $0.0-2.0$ & $2.63-3.0$ & $0.0-0.8$ & $0.3 \sim 0.7$ & 1.921 .6 & $-9.9+3.1$ & $6,200 \pm 320$ \\
\hline 12 & $-11.8 \div 0.5$ & 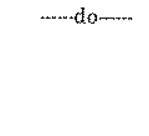 & $\begin{array}{l}\text { Abundant roots in } \\
\text { growth positions; } \\
\text { Trochemmina } \\
\text { inflata (Fa); } \\
\text { Cymbella (Op). }\end{array}$ & $0.7 \pm 0.7$ & 0 & 0 & 0 & 0 & 0 & 0 & $-12.5 \pm 1.2$ & $6,485+110$ \\
\hline 21 & $-9.2 \pm 0.3$ & ......don. & $\begin{array}{l}\text { Abundant roots, prob. } \\
\text { ably in growth } \\
\text { positions; } \\
\text { Campylouiscus (Dp). }\end{array}$ & $0.9 \pm 0.9$ & $0.5-2.5$ & $0.2-5.0$ & 0 & 0 & 0 & $2.6 \pm 2.4$ & $-7.5 \pm 3.6$ & $6.855 \pm 115$ \\
\hline il & $-24.6+0.7$ & 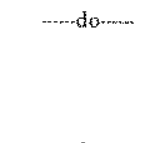 & $\begin{array}{l}\text { Abundant roots, prob- } \\
\text { ably in growth } \\
\text { positions: } \\
\text { Compylodiscus (Dp); } \\
\text { framboidal pyrite. }\end{array}$ & $0.7 \pm 0.7$ & $1.5-2.5$ & $0.6-5.0$ & $20-3.0$ & $0.0-0.8$ & 0 & $3.2 \pm 2.6$ & $-22,1 \pm 4.0$ & $8,23041,3 \pi$ \\
\hline $10^{3}$ & $-21.0+1.0$ & ardoman & $\begin{array}{l}\text { Abundant roots, prob- } \\
\text { ably in growth } \\
\text { positions; Trocham- } \\
\text { mina sp. (Fa); } \\
\text { Campylodiscus (Dp), } \\
\text { Hyalodiscus (Dc). }\end{array}$ & $0.7 \pm 0.7$ & $0.0-2.0$ & $0.0-4.0$ & $0.0-2.0$ & $0.0-0.5$ & 0 & $2.2 \pm 2.2$ & $-19.5 \pm 3.9$ & $8,295 \pm 135$ \\
\hline 16 & $-18.7+0.3$ & .......do-non... & $\begin{array}{l}\text { Abundant roots, prob- } \\
\text { ably in growth } \\
\text { positions; } \\
\text { Campylodiscus (Dp). }\end{array}$ & $0.9 \pm 0.9$ & $0.0-1.0$ & $0.0-2.0$ & $2.0-3.0$ & $0.0-0.8$ & $\theta$ & $1.4+1.4$ & $-18.2+2.6$ & $8,365+135$ \\
\hline $3^{3}$ & $-32.5+1.0$ & $\begin{array}{l}\text { Remains of } \\
\text { fresh-or } \\
\text { brackigh- } \\
\text { water } \\
\text { marsh } \\
\text { plants }\end{array}$ & $\begin{array}{l}\text { Abundant roots in } \\
\text { growth positions, } \\
\text { and abundant } \\
\text { Scirpus? seeds }(A, f) \\
\text { rare limonitized } \\
\text { framboidal pyrite. }\end{array}$ & $\begin{array}{l}\text { Probably } \\
\text { above } \\
\text { highest } \\
\text { tides. }\end{array}$ & 0 & 0 & $0-2$ & $0-2$ & 0 & $1 \dot{1} 1$ & $\begin{array}{l}\text { Below } \\
-31.5420\end{array}$ & $8,885 \pm 145$ \\
\hline 4 & $-39.5 \pm 0.5$ & $\begin{array}{l}\text { Chunks of } \\
\text { wood. }\end{array}$ & $\begin{array}{l}\text { Abundant detrital } \\
\text { wood; Ammonia } \\
\text { beccarin, Elphidium } \\
\text { sp. (Fc); Cythero. } \\
\text { morpha sp. (O); } \\
\text { Cocconeis, Surirella, } \\
\text { Cymbella (Dp); } \\
\text { Valvala (G, f); } \\
\text { Psidium (G, D); } \\
\text { Thoecamoebina } \\
\text { (fresh- and brackish. } \\
\text { water protozoans); } \\
\text { mosquito larvae } \\
\text { (R. E. Amal, writter } \\
\text { commun, 1974). }\end{array}$ & $0.0 \pm 1.5$ & 0 & 0 & 0 & 0 & 0 & 0 & -39.542 .0 & $9,255 \pm 310$ \\
\hline
\end{tabular}


Table 2.-Data on Holocene sea levels-Continued.

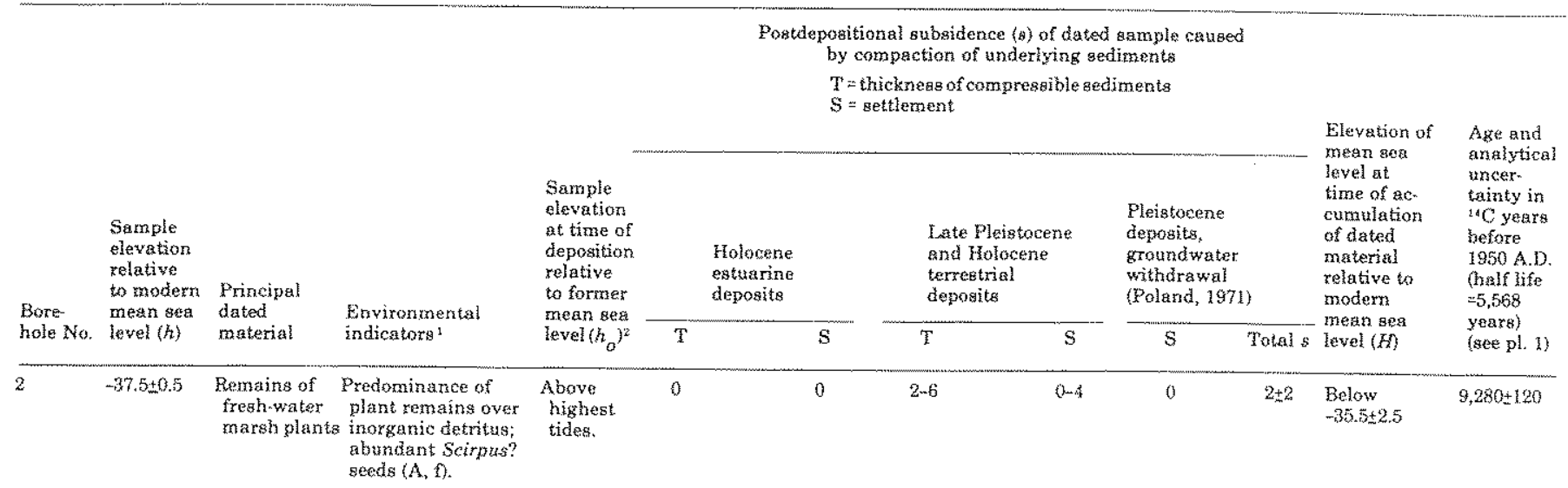

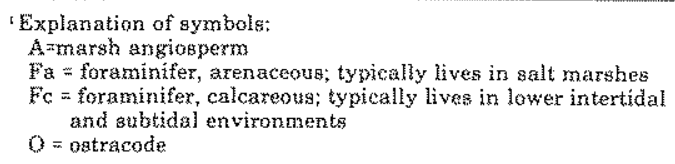

$D p=$ diatom, pennate
$D c=$ diatom, centric
$P=$ pelecypod
$G=$ stastropod
\& = salinity range predominantly taltwater and brackish water
$f=$ salinity range predominantly brackish water and freshwater

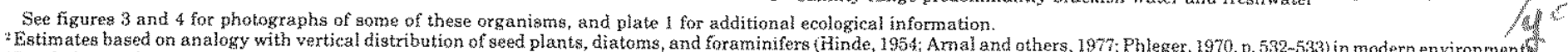
Borehole not shown on cross sections (pl. 1).

amplitude sea-level oscillations, so a smoothed curve was visually fitted to the data points (fig. 6). This curve displays a more than tenfold decrease in slope between 8,000 and 6,000 years ago. On the average, sea level in the vicinity of southern San Francisco Bay rose about $2 \mathrm{~cm} /$ yr from 9,500 to 8,000 years ago, but it has risen only $0.1-0.2 \mathrm{~cm} / \mathrm{yr}$ from 6,000 years ago to the present. A similar change in rate appears in sea-level records from other parts of the world (for example, Milliman and Emery, 1968) and probably coincides with the disappearance of the large Wisconsin ice sheets (Bloom, 1971, p. 368).

Extrapolation of the sea-level curve to the presumed late Wisconsin base level, located about $65-70$. $m$ below modern sea level at the Golden Gate ( $A$, fig. 7 ), indicates that the rising sea entered the Golden Gate 10,000-11,000 years ago. Driven by the sea-level rise of several centimeters per year, an estuary then spread rapidly, advancing about $30 \mathrm{~m} / \mathrm{yr}$ along the course of the trunk stream draining the site of southern San Francisco Bay and reaching the vicin. ity of Menlo Park by $8,000(G$, fig. 7 ) years ago (fig. 7 ). Subsequent shoreline changes have been more gradwal because of the decrease in rate of sea-level rise.

A change from predominantly fresh-and brackish-water diatoms in estuarine sediments about $8,500-9,300$ years old to predominantly marine diatom assemblages in younger sediments (boreholes $4,5,6$, section $A-A^{\prime}$, pl. 1) indicates increasing salinity. This increase was probably caused by the rapid early growth of the estuary. Assuming a nearly constant long term inflow of freshwater, the large increases in water volume accompanying this growth should have resulted in substantially greater

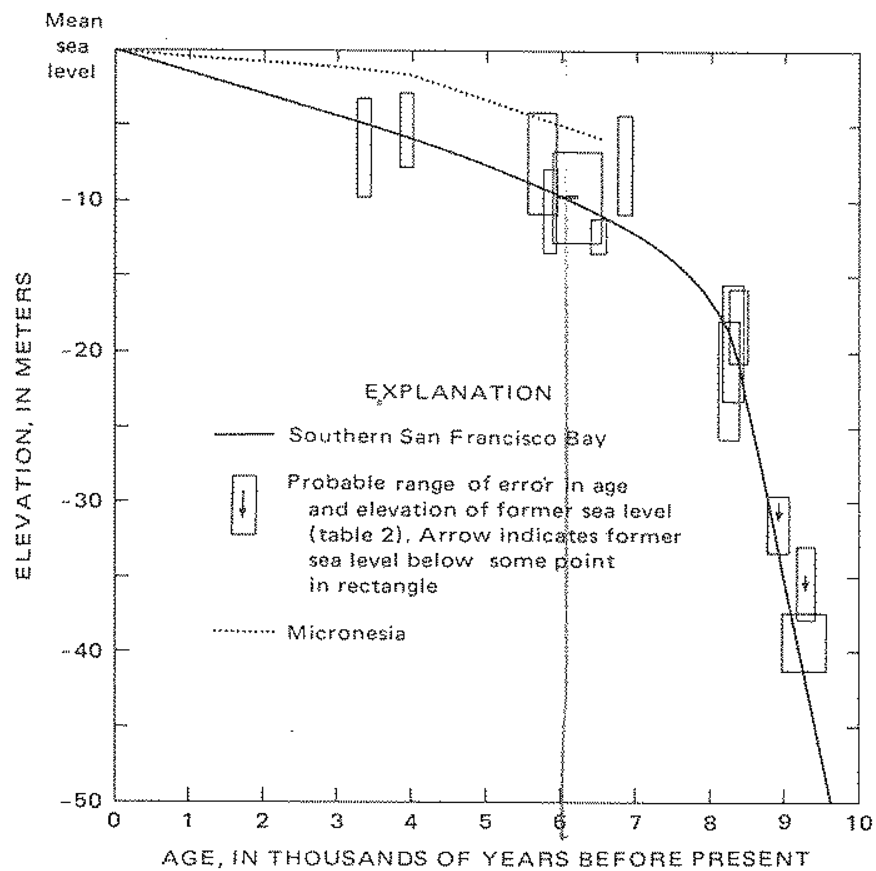

Flgure 6.-Holocene sea-level changes in the vicinity of southern San Francisco Bay. The curve for Micronesia, shown for comparison, approximates Holocene eustatic sea-level changes according to Bloom (1970, p. 1901).

average water salinities by permitting larger proportions of saltwater to enter the estuary.

Changing rates of sea-level rise largely control the stratigraphic distribution of salt-marsh deposits. The sea-level rise of several centimeters per year probably exceeded most local sedimentation rates, so tidal marshes before 8,000 years ago were scarce and small and, moreover, were ultimately submerged by 

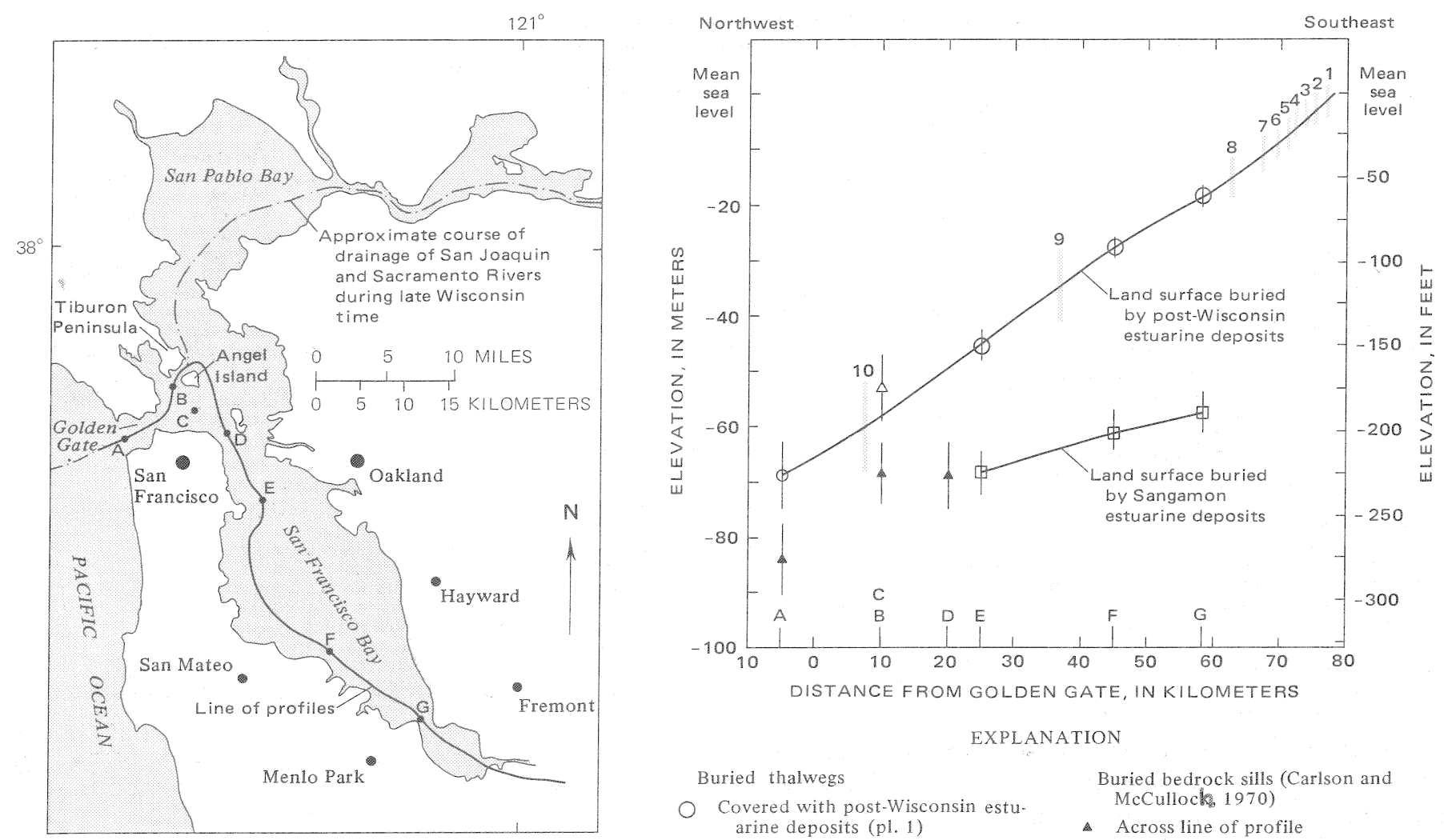

$$
\begin{aligned}
& \text { Buried thalwegs } \\
& \text { Covered with post-Wisconsin estu- } \\
& \text { arine deposits (pl. 1) } \\
& \text { Covered with sediments, probably } \\
& \text { of post-Wisconsin age, recogniz- } \\
& \text { ed in seismic reflection profiles } \\
& \text { (Carlson and others, 1970, } \\
& \text { p. 105) } \\
& \text { Covered with Sangamon estuarine } \\
& \text { deposits; elevations estimated } \\
& \text { from unpublished borehole logs } \\
& \text { and cross sections by Calif. Div. } \\
& \text { of Bay Toll Crossings, 1948-71 }
\end{aligned}
$$

\author{
Buried bedrock sills (Carlson and \\ McCullock 1970) \\ $\triangle$ Across line of profile \\ $\triangle$ Not across line of profile \\ 8 Radiocarbon age of Holocene sea \\ level in $10^{3}$ years before pres - \\ ent (fig. 6)
}

Figure 7.-Longitudinal profiles of buried land surfaces under southern San Francisco Bay. Profiles are based primarily on the elevations of buried thalwegs (lines of maximum valley depth) at points $\mathrm{A}, \mathrm{E}, \mathrm{F}$, and $\mathrm{G}$. Point $\mathrm{E}$ is located between boreholes 4 and 5 $\left(A-A^{\prime}\right.$, pl. 1), point F, approximately at borehole $17\left(B-B^{\prime}\right.$, pl. 1$)$, and point $\mathrm{G}$, between boreholes 32 and $34\left(C-C^{\prime}\right.$, pl. 1$)$. The upper profile is also based on the elevations of bedrock sills (points $A, B$, and D), which indicate the deepest possible base levels during late Wisconsin time. All vertical bars show approximate uncertainties in elevations of thalwegs and sills. We speculate that the late Wisconsin trunk stream draining the site of southern San Francisco Bay met the drainage of the San Joaquin-Sacramento Rivers north and east of Angel Island because the bedrock sill between Angel Island and Tiburon Peninsula (B) is about $15 \mathrm{~m}$ lower than the sill between San Francisco and Angel Island (C); therefore the profile of the land surface buried by post-Wisconsin estuarine deposits loops north of Angel Island. The intersection of Holocene sea levels with this profile shows the rapid longitudinal growth of the post-Wisconsin estuary from 10,000 to 8,000 years ago and the subsequent decline in the rate of longitudinal growth.

the rising sea. Later, the declining rate of sea-level rise was approached and finally surpassed by the rate of sediment accumulation in much of the estuary, permitting progradation of mudflats and salt marshes. Most of the bayward growth of marshes has occurred during the past several thousand years, as evidenced by the lower intertidal and subtidal deposits which typically lie no more than a few meters below mean sea level beneath the historic salt marshes (boreholes 13, 26, 27, 29, 30, 32, 38, 39, sections $B-B^{\prime}$ and $C-C^{\prime}$, pl. 1).

\section{VERTICAL MOVEMENT OF THE EARTH'S CRUST}

EVIDENCE AND RATES OF SUBSIDENCE

Evidence of vertical crustal movement at the site of southern San Francisco Bay was first reported by Lawson (1914, p. 3), who observed that late Cenozoic structural features bound the valley that is partly flooded by the bay. Subsequently, Louderback (1951, p. 83) proposed that the bedrock surface under this valley had been downwarped during Quaternary time. Both men asserted that the valley containing southern San Francisco Bay had been shaped not only by running water but also by vertical tectonic movement of the Earth's crust.

Several additional lines of evidence suggest that subsidence of the valley floor has taken place and permit rough estimates of the rates of subsidence (table 3): (1) Quaternary(?) sediments are situated at least $200 \mathrm{~m}$ below present sea level, (2) Wisconsin 
TAELE 3.-Evidence and inferred rates of crustal downwarping in the vicinity of southern San Francisco Bay

\begin{tabular}{|c|c|c|c|c|}
\hline Evidenet & $\begin{array}{c}\text { Kate } \\
(\pi, m / y x)\end{array}$ & How masured & Time period & Origin \\
\hline $\begin{array}{l}\text { Quaternary(?) sedi- } \\
\text { ments situated at } \\
\text { least } 200 \mathrm{mo} \text { below } \\
\text { present saa level. }\end{array}$ & $i>0.0 \%$ & $\begin{array}{l}\text { Elevation difference } \\
\text { between deepest } \\
\text { quaternary sedi- } \\
\text { ments and level at } \\
\text { which they were } \\
\text { probably deposited. }\end{array}$ & 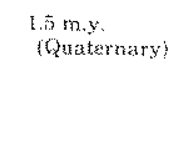 & Tectomic \\
\hline $\begin{array}{l}\text { Wisconsin thalweg } \\
\text { situated higher } \\
\text { than the deepest } \\
\text { Sangamon estu. } \\
\text { arine deposits. }\end{array}$ & $\begin{array}{l}20.2 \pm 0.1 \\
9.4 \pm 0.1 \\
10.4 \pm 0.1\end{array}$ & $\begin{array}{l}\text { Differences in aleva } \\
\text { tion between the } \\
\text { thalwegs covered } \\
\text { with sangamon } \\
\text { and post-Wisconsin } \\
\text { estuarine deposits } \\
\text { (fig. 6). }\end{array}$ & $\begin{array}{l}\text { 0.1 my. } \\
\text { late Pleisto. } \\
\text { cene; Sangamon } \\
\text { and Wisconsin. }\end{array}$ & De. \\
\hline $\begin{array}{l}\text { Relative sealevel } \\
\text { rise is rreater } \\
\text { than that expected } \\
\text { from eustatic sea } \\
\text { level changes alone. }\end{array}$ & $0.8+0.7$ & $\begin{array}{l}\text { Comparison of post- } \\
\text { Wisconsin sea } \\
\text { levels at south. } \\
\text { ern San Francisce } \\
\text { Bay with those at } \\
\text { Micronesia, an area } \\
\text { af presumed crustal } \\
\text { stability (fig. 5). }\end{array}$ & $\begin{array}{l}6,000 \text { years } \\
\text { (Holocene) }\end{array}$ & $\begin{array}{l}\text { Tectonic } \\
\text { and } \\
\text { possibly } \\
\text { isostatic }\end{array}$ \\
\hline
\end{tabular}

IApplies to most of site of southern San Francisco Bay below latitude of Hayward "Applies to site betweer boreholes 4 and $5\left(A-A^{\prime}\right.$, pl. 1$)$.

Applies to site near borehole $17\left(B-B^{\prime}\right.$, pl. 1$)$.

Applies to site betwen borehroles 32 and $34(C-C$. pl. 1$)$.

trunk streams were unable to cut through the deepest Sangamon estuarine deposits, and (3) the late Holocene rise in sea level exceeds what might be expected from eustatic sea-level changes alone.

\section{QUATERNARI SEDMENTS AT LEAST $200 \mathrm{M}$} BELOW PRESENT SEA LEVEL

Sediments of Quatemary age may extend at least $200 \mathrm{~m}$ below present sea level under much of southern San Francisco. Bay, particularly between San Mateo and Hayward and between Menlo Park and Fremont (Finlayson and others, 1967, pl. 5; Meade, 1967, p. 40-41). Assuming that they were deposited during the past 1.5 million years and within $100 \mathrm{~m}$ of present sea level, these sediments probably have been lowered by tectonic subsidence of at least $0.07 \mathrm{~mm} / \mathrm{yr}$.

Conceivably, an extremely low stand of sea level could have allowed streams draining the bay basin to grade to a base level $200 \mathrm{~m}$ below present sea level, thereby allowing Quaternary sediments to accumulate at lower elevations than we assume. However, such a stand of the sea during Pleistocene time is unlikely because it is lower than what might be expected from ice volumes during Pleistocene glacial maxima (Flint, 1971, p. 84) or from the overall rise of sea level independent of glacioeustatic fluctuations (Vasil'kovskiy, 1973, p. 857).

WISCONSIN THALWEGS HGHER THAN THE DEEPEST SANGHMON ESTUARINE DEPOSTS

The volume of Sangamon estuarine deposits remaining after Wisconsin erosion appears to be close to the volume of post-Wisconsin estuarine sediments under most of southern San Francisco Bay (pl. 1). The Sangamon deposits persisted in such quantity because Wisconsin trunk streams were unable to cut through them: the thalwegs (lines of maximum valley depth) of Wisconsin trunk stream are located at least $15 \mathrm{~m}$ above the deepest Sangamon estuarine deposits. Assuming that the trunk stream draining the bay basin during the low stand of sea level before the first major marine transgression of Sangamon age was similar in location, base level, and gradient to the trunk streams during the major low stands of sea level of Wisconsin age, the early Sangamon estuarine deposits must be tectonically depressed below the Wisconsin thalwegs.

The differences in elevation between the ancient land surfaces covered with Sangamon and postWisconsin estuarine deposits should approximate the magnitude of this tectonic subsidence during Sangamon and Wisconsin time, a period of about 100,000 years. Assuming that the initial longitudinal profiles of these land surfaces were similar in gradient and elevation, the present differences in elevation between the profiles (fig. 7) indicate the following average rates of tectonic subsidence : $0.2 \pm 0.1$ $\mathrm{mm} / \mathrm{yr}$, between San Francisco and Oakland; $0.4+0.1 \mathrm{~mm} / \mathrm{yr}$, between San Mateo and Hayward and between Menlo Park and Fremont.

RELATIVE SEA-LEVEL RISE GREXTER THAN TIYAT EXPECTED FROM EUSTATICSEA-IEVEL CHANCESALONE

The record of post-Wisconsin sea levels at south ern San Francisco Bay can be used as a datum to determine vertical crustal movement by comparison with sea-level data from areas of presumed crustal stability. Sea level has risen more rapidly in the vicinity of southern San Francisco Bay than in Micronesia by $0.8 \pm 0.7 \mathrm{~mm} / \mathrm{yr}$ during the past 6,000 years (fig. 6). Assuming that the relative sea-level rise in Micronesia approximates purely eustatic changes (Bloom, 1970, p. 1901), the more rapid submergence at the site of southern San Francisco Bay represents downward crustal movement.

Tectonic subsidence is probably the principal component of this crustal movement. Given the range of our uncertainties, the rates of tectonic subsidence during the last 100,000 years of Pleistocene time may be considered equivalent to the rate of late Holocene crustal downwarping (table 3). If the actual rate of Holocene downwarping is as high as 1 $\mathrm{mm} / \mathrm{yr}$, however, then tectonic subsidence has accelerated or has been augmented by isostatic downwarping of the continental margin. The likelihood of isostatic adjustment to post-Wisconsin seawater loads has been established for the Atlantic coast of the United States by Bloom (1967.b), but at present we cannot differentiate its effects from those of tec- 
tonic subsidence in the vicinity of southern San Francisco Bay.

AGE OF THE WEDROCK DEPRESSION CONTANING SOUTHERN SAN FRANCISCO BAN

Rates of tectonic subsidence can be extrapolated to estimate the age of the structural trough that contains southern San Francisco Bay. For example, the top of Mesozoic bedrock under southern San Francisco Bay is located as much as $200 \mathrm{~m}$ below present sea level near Menlo Park (R. M. Hazelwood, oral commun., 1975). Assuming that streams flowing in this area cut no deeper than $100 \mathrm{~m}$ below present sea level during a Pleistocene glaciation, this bedrock surface has undergone at least $100 \mathrm{~m}$ of tectonic subsidence. Extrapolation of local tectonic subsidence rates, which averaged $0.3-0.5 \mathrm{~mm} / \mathrm{yr}$ during Sangamon and Wisconsin time, indicates that this subsidence began as recently as $0.2-0.3$ m.y. ago.

The structural trough appears to be older in some other areas. The depth to bedrock along the east shore of southern San Francisco Bay near Hayward, for instance, probably exceeds $300 \mathrm{~m}$ (R. M. Hazelwood, oral commun., 1975). At subsidence rates of $0.3-0.5 \mathrm{~mm} / \mathrm{yr}$, this depth suggests an age of at least $0.4-0.7 \mathrm{~m} . \mathrm{y}$. Furthermore, a tuff about $1 \mathrm{~m} . \mathrm{y}$. old is found in estuarine sediments $87 \mathrm{~m}$ below present sea level in borehole 2 (table 1). This tuff indicates that a structural trough may have been located just east of the site of San Francisco during early Pleistocene.

\section{SUMMARY AND CONCLUSIONS}

1. Two units of estuarine deposits are recognized in sediments less than $60 \mathrm{~m}$ below present sea level at the site of southern San Francisco Bay (table 1; pl. 1). These deposits were produced by Sangamon and post-Wisconsin high stands of sea level (fig. 2). Estuarine sediments of middle Wisconsin age appear to be absent, suggesting that local sea level was not near its present height 30,000-40,000 years ago. 2. The estuarine deposits of Sangamon and postWisconsin age are separated by alluvial and eolian deposits and by erosional unconformities and surfaces of nondeposition (pl. 1). These features indicate lowered base levels and oceanward migrations of the shoreline accompanying low stands of the sea.

3. The late Wisconsin shoreline was situated some distance west of the site of San Francisco (fig. 1). The rising post-Wisconsin sea entered the Golden Gate 10,000-11,000 years ago. As sea level rose about $2 \mathrm{~cm} / \mathrm{yr}$, an estuary spread across adjacent land areas as rapidly as $30 \mathrm{~m} / \mathrm{yr}$ until about 8,000 years ago. Subsequent inundation has been more gradual because the rate of sea-level rise has declined at least tenfold since 8,000 years ago, averaging only $0.1-0.2$ $\mathrm{mm} / \mathrm{yr}$ from 6,000 years ago to the present (figs. 6, 7). 4. Some of the sediments under southern San Francisco Bay appear to be situated below the level at which they initially accumulated. The vertical crustal movement suggested by these sediments (table 3) may be summarized as follows: (a) Some Quaternary(?) sediments have tectonically subsided at least $0.07 \mathrm{~mm} / \mathrm{yr}$ relative to the lowest likely Pleistocene land surface; (b) the deepest Sangamon estuarine deposits have subsided tectonically $0.2-0.4 \pm 0.1 \mathrm{~mm} / \mathrm{yx}$ relative to the assumed initial elevations of the thalwegs buried by these sediments; and (c) Holocene salt-marsh deposits have undergone about $0.8 \pm 0.7 \mathrm{~mm} / \mathrm{yr}$ of tectonic and possibly isostatic subsidence relative to elevations that might be expected from eustatic sea-level changes alone.

5. Rates of tectonic subsidence and the depth to Mesozoic bedrock indicate that the structural depression containing southern San Francisco Bay may be as young as $0.2-0.3 \mathrm{~m} . \mathrm{y}$. in some areas.

\section{RETERENCES CITED}

Arnal, R. E., Quinterno, P. J., Conomos, T. J., and Gram, K., 1977, Trends in the distribution of recent Foraminifera in San Francisco Bay: Springer-Verlack, Bandy memorial volume in micropaleontology (in press).

Atwater, B. F., and Hedel, C. W., 1976, Distribution of tidal-marsh plants with respect to elevation and water salinity in the natural tidal marshes of the northern San Francisco Bay estuary, California: U.S. Geol. Survey, open-file report $76-$ $389,41 \mathrm{p}$.

Bastin, E. S., and Davis, C. A., 1909, Peat deposits of Maine: U.S. Geol. Survey Bull, 376, 127 p.

Berggren, W. A., and VanCouvering, J. A., 1975, The Late Neogene: Palaeogeography, Palaeoclimatology, Palaeoecology, v. 16, p. $1-216$.

Birkeland, P. W., 1972, Late Quaternary eustatic sea-level changes along the Malibu Coast, Los Angeles County, California: Jour, Geology, v. 80, p. 432-448.

Bloom, A. L., 1964, Peat accumulation and compaction in a Connecticut coastal marsh: Jour. Sed. Petrology, v. 34, no, 3, p. 599-603.

1967a, Coastal geomorphology of Connecticut; Final Rept., Geography Br., Office Naval Research, contract NORN-401 (45), $72 \mathrm{p}$.

1967b, Pleistocene shorelines, a new test of isostasy: Geol. Soc. America Bull., v, 78, p. 1.777-1494.

1970, Paludal stratigraphy of Truk, Ponape, and Kusaie, Eastem Caroline Islands: Geol. Soc. America Bull., y. 81, p. 1895-1904.

1971, Glacialeustatic and isostatic controls of sea level since the last glaciation, in Turekian, K. K., ed., The late Cenozoic glacial ages: Yale Univ. Press, p. 355-379.

Bonilla, M. G., 1959, Geological observations in the epicentral area of the San Francisco earthquake of March, 1957: Califormia Div. Mines Spec. Rept. 57, p. 25-37.

1965, Geologic map of the San Francisco south quadrangle, California: U.S. Geol. Survey open-file map, scale 1:20,000.

Broecker, W. S., and VanDonk, J., 1970, Insolation changes, ice 
volumes and the 150 record in deep-sea cores: Rev. Geophysics and Space Physics, v. 8, p. 169-198.

California Division of Bay Toll Crossings, 1966, Final report of preliminary soil exploration for a southern crossing of San Francisco Bay: California State Dept. Public Works, 72 p.

Carlson, P. R., Alpha, T. R, and McCulloch, D. S., 1970, The floor of San Francisco Bay: California Geology, v. 23, p. 97107.

Carlson, P. R., and McCulloch, D. S., 1970, Bedrock-surface map of central San Francisco Bay, California: U.S. Geol. Survey open-file map, scale $1: 27,200$.

Chappell, John, 1974, Geology of coral terraces, Huon Peninsula, New Guinea-A study of Quatemary tectonic movements and sea-level changes: Geol. Soc, Amexica Bull., v. 85, p. 553-570.

Cooper, W. S., 1967, Coastal dunes of California: Geol. Soc. America Mem. 104, $131 \mathrm{p}$.

Finlayson, D. J., Hansen, W. R., Ford, R. S., Scott, R. G., and Vantine, J. V., 1967, Evaluation of ground water resources, south Bay-App. A, geology: California Dept. Water Resources Bull. 118-1, $153 \mathrm{p}$.

Flint, R, F, 1971, Glacial and Quaternary geology: John Wiley and Sons, New York, $892 \mathrm{p}$.

Gilbert, G. K., 1917, Hydraulic-mining debris in the Sierra Nevada: U.S. Geol. Survey Prof. Paper 105, 154 p.

Hall, N. T., 1966, Late Cenozoic stratigraphy between Mussel Rock and Fleischhackex Zoo, San Francisco Peninsula, in A walker's guide to the geology of San Francisco: California Div. Mines and Geology, Spec. Supp. Mineral Inf. Service, v. 19 , no. 11 , p. $22-25$.

Hanna, G. D., 1944, Diatomaceae, in Shimer, H. W., and Shrock, R. R., editors, Index fossils of North America: New York, John Wiley and Sons, Inc., $837 \mathrm{p}$.

Helley, E.J., Lajoie, K. R., and Burke, D. B., 1972, Geologic map of Late Cenozolc deposits, Alameda County, California: U.S. Geol. Survey Misc. Field Studies Map MF-429, scale 1:62,500.

Hinde, H. P., 1954, Vertical distribution of salt marsh phanerogams in relation to tide levels: Ecol. Mon., v. 24, p. 209.225.

Kaye, C. A., and Barghoorn, E. S., 1964, Late Quatersary sealevel change and crustal rise at Boston, Massachusetts, with notes on the autocompaction of peat: Geol. Soc. America Bull., v. 75, p. $63-80$.

Lajoie, K. R., Helley, E. J., Nichols, D. R., and Burke, D. B., 1974 , Geologic map of unconsolidated and moderately consolidated deposits of San Mateo County, Callfornia: U.S. Geol. Survey Misc. Field Studies Map MF-575, scale 1:62,500.

Lawson, A. C., 1894, The geomorphogeny of the coast of Northern California: California Univ. Dept. Geology Bull., v. 1, p. 241271.
1914, Geology of the San Francisco District: U.S. Geol. Survey United States, Geol. Atlas, 24 p.

Louderback, G. D., 1941, Development of San Francisco Bay abs. : Geol. Soc. America Bull., v. 52, p. 1952.

1951, Geologic history of San Francisco Bay, in Jenkins, O. P., ed., Geologie guidebook to the San Francisco Bay counties: California Div. Mines Bull. 154, p. 75-94.

Meade, R. H., 1967, Petrology of sediments underlying areas of land subsidence in central California: U.S. Geol. Survey Prof. Paper 497-C, $83 \mathrm{p}$.

Milliman, J. D., and Emery, K. O., 1968, Sea levels during the past 35,000 years: Science, v. 162, p. 1121-1123.

Nichols, D. R., and Wright, N. A, 1971, Preliminary map of historic margins of marshland, San Francisco Bay, California: U.S. Geol. Survey open-tile map, scale 1:125,000.

Phleger, F. B., 1970, Foraminiferal populations and marine marsh processes: Limnology and Oceanography, v, 15, p. 522-534.

Poland, J. F, 1971, Land subsidence in the Santa Clara Valley, Alameda, San Mateo, and Santa Clara Counties, California: U.S. Geol. Survey Misc. Field Studies Map MF $* 336$, scale $1: 125,000$.

Radbruch, D.H., and Schlocker, Julius, 1958, Engineering geology of the Islais Creek Basin, San Francisco, California: U.S. Geol. Survey Misc. Geol. Inv. Map I-264, scale 1:12,000.

Sarna-Wojcicki, Andrei, 1976, Correlation of late Cenozoic tuffs in the central Coast Ranges of California by means of trace- and minor-element chemistry: U.S. Geol. Survey Prof. Paper 972, $30 \mathrm{p}$.

Schlocker, Julius, Bonilla, M. G, and Radbruch, Dorothy, 1958 , Geology of the San Francisco North quadrangle, California: U.S. Geol. Survey Misc. Geol. Inv. Map I-272, scale 1:24,000.

Trask, P. D., and Rolston, J.W., 1951, Engineering geology of San Francisco Bay, California: Geol. Soc. America Bull., v. 62 , p. $1079-1110$.

Treasher, R. C., 1963, Geology of the sedimentary deposits in San Francisco Bay, California: California Div. Mines and Geol. Spec, Rept. 82 , p. 11-24.

Vasil'kovskiy, N. P., 1973, Sea level changes in the geological past: P. P. Shirshov Inst. Oceanology, U.S.S.R. Acad. Sciences, p. 847-859.

Wahrhaftig, Clyde, and Birman, J. H, 1965, The Quaternary of the Pacific mountain system in California, in Wright, H. E., Jr., and Frey, D. G., eds., The Quaternary of the United States; Princeton Univ. Press, p. 299-340.

Weller, J. M, 1959, Compaction of sediments: Am. Assoc. Petroleum Geologists Bull., v. 43, no. 2, 273-310. 
